\title{
BROWN V LEYDS NO (1897) 4 OR 17: A CONSTITUTIONAL DRAMA IN FOUR ACTS. \\ ACT ONE: THE 1858 CONSTITUTION OF THE ZUID-AFRIKAANSCHE REPUBLIEK*
}

\section{Derek van der Merwe**}

\section{ABSTRACT}

This is the first of a series of articles on the historical and jurisprudential background to the well-known judgement of Chief Justice John Kotzé in Brown v Leyds NO (1897) 4 OR 17. Central to the Brown judgement was the liberal interpretation Chief Justice Kotzé attached to the 1858 Constitution (the Grondwet) of the South African Republic (the Zuid-Afrikaansche Republiek). The articles traces the jurisprudential history of the Grondwet, from the earliest conceptions of statehood adopted by the Voortrekkers of the Great Trek, to the first feeble forms of Republican government adopted by the Boers. It then describes the different ideological conceptions within the Boer society of the trans-Vaal region that came to be attached to the notion of the "volkstem" (the voice of the people) as an expression of the "volkswil" (the will of the people). These different ideological conceptions were best captured as responses to the question "Wie heeft de Koningstem?" ("Who has the King's voice?"). These ideological differences gave rise to political differences that inhibited the framing of a proper constitution for the territory for six years. Various attempts

* This article, and subsequent articles, are based on and contain many extracts from my book entitled Brown v Leyds: Who has the King's Voice? which will be published by Lexis Nexis in 2017.

** Emeritus Professor of Law, University of Johannesburg. 
at drafting a constitution are described, as are the compromises that were reached and the distinctions that were drawn in order to reach a position where, in February 1858, a Constitution that carried the approval of all the people was finally adopted. This history, in which Paul Kruger, the later State President, played an integral part, is important for a proper understanding of why the judgment adopted by Kotzé in Brown was untenable, laudable though his motives were.

KEYWORDS: Constitution; Zuid-Afrikaansche Republiek (South African Republic); Dutch/Cape Patriots; Boers; volk (the people); volkstem (voice of the people); vox populi vox Dei; the King's voice; governance; hoogste gezag (highest authority); Volksraad (council of the people); eenhoofdig bestierder (autocratic leader); maatschappij (society)

\section{Introduction}

On 22 January 1897, 120 years ago, Chief Justice John Kotzé handed down a judgement in the Supreme Court of the old South African (Transvaal) Republic (ZuidAfrikaansche Republiek) in the matter of Brown v Leyds NO. ${ }^{1}$ It was a momentous decision with far-reaching consequences, as South African constitutional lawyers and legal historians well know. In his judgement (supported by Judge Ameshoff in a separate judgement, but dissented from by Judge Morice, also in a separate judgement) Kotzé introduced and applied the doctrine of judicial review of executive and legislative action by "testing" the validity of such action against the provisions of the Republican Constitution. In doing so he was a century ahead of his time, seeking, as he did, to apply American (and Dutch) jurisprudence to a constitution wholly unsuited to serve as his doctrinal foundation and in a political climate wholly unreceptive to such a jurisprudence. The result was that he was dismissed from his position as Chief Justice - the first and only time a judge has been "impeached" in South Africa. This extraordinary act on the part of State President Paul Kruger and his executive council contributed in no small measure to the agitation by British High Commissioner Alfred Milner and like-minded imperialists for Great Britain to take over the affairs of a Transvaal State deemed incapable of governing itself properly and to protect the (primarily commercial) interests of British and other foreign inhabitants. It became an important secondary cause of the Anglo-Boer War that broke out some eighteen months after the dismissal of Kotzé by Paul Kruger.

Scholars of international law will also know that the Brown judgement had international repercussions too. Robert Brown, an American citizen, whose demand, in July 1895, to be allowed to work the gold claims he had pegged off on a newly proclaimed public digging on the western edges of the Witwatersrand, had been

1 (1897) 4 OR 17. Judgements were handed down by Kotze (CJ, Ameshoff J and Morice

J. Biographical details on each of these judges will be provided in Part 2 (Kotze) and Part 3

(Ameshoff and Morice) of this series of articles. 
approved in Brown, struggled in vain to exercise his right to work the claims after Kotzé's dismissal. He finally sought the assistance of the United States government to demand from Great Britain redress for the injustice he had suffered before and after the Anglo-Boer War. The matter became the subject of an international arbitration. An international arbitral tribunal heard the matter only in 1923, twenty one years after Brown's early death. It decided that Great Britain had no obligation in international law to provide redress for an injustice suffered by an individual at the hands of a conquered state. ${ }^{2}$

This and subsequent articles seek to provide historical and jurisprudential flesh to the famous judgement of Brown $v$ Leyds NO.

Context is crucial, in law as in life. The Brown judgement was based on a particular interpretation of the 1858 Grondwet (Constitution) of the Zuid-Afrikaansche Republiek ("ZAR"). It was an interpretation that flew in the face of the intent of the original framers of the constitution, an interpretation that Kotzé did not originally hold and an interpretation that Paul Kruger publicly denounced as the principle of the Devil, proclaimed by one who must be mentally unbalanced. The Grondwet, therefore, was the centrepiece around which battles political, jurisprudential and commercial were fought. The first of the articles investigates the ideological origins of the Grondwet and the various stages of the formulation of the relevant sections in the Grondwet, until its final conflict-ridden, compromise-driven approval by the volk (the people) at Rustenburg in January 1858.

A subsequent article will firstly analyse case law from the 1880s and early 1890 s which reflect the initial views expressed by Kotzé (and other judges) on the right which the judiciary could or should arrogate to itself to "test", by means of judicial review, the validity of executive action and legislative enactments by reference to apposite provisions in the Grondwet. The analysis will highlight the social and political influences on Kotzé that brought about in him a jurisprudential aboutturn and made him such a zealous and - as it turned out - hopelessly premature proponent of constitutional supremacy. Secondly, the case of Brown v Leyds NO will receive dedicated attention: The events that gave rise to Brown's claim against the state; the political background against which Kotzé and his co-judges prepared their judgements; the judgement of Kotzé and also of the Hollander, Ameshoff, and the Scotsman, Morice; the political repercussions of the judgement; and Kotzé's dismissal, reactions to and consequences of the dismissal.

A final article will describe the attempts made by Robert $\mathrm{E}$ Brown to exercise his rights in the shadow of a hostile administration and a supreme court with a very different personnel from the Kotzé court; his futile efforts to convince the post-war British colonial administration to secure his rights; the eventual resort to international arbitration between the United States and Great Britain; and the limp-wristed findings

2 Robert E Brown (United States) v Great Britain Reports of the International Arbitral Awards (RIAA) VI 120. 
of the arbitral panel in 1923 that brought an end to the Brown saga a quarter of a century later. Hitherto un-researched archival material in the United States National Archives in Washington, DC, provided a fertile source of information on Brown's valiant efforts to secure justice for himself and his descendants in the international arena.

\section{$2 \quad$ Wie heeft de Koningstem? ("Who has the King's voice?"): The politics of Constitution-making among the trans-Vaal Boers of the mid-nineteenth century}

\section{Conceptions of statehood among the Voortrekkers (1836- 1843)}

"[We will] walk out by the Draaksberg barefooted, to die in freedom, as death [is] dearer to [us] than the loss of liberty": Susanna Smit, a voortrekker woman ${ }^{3}$

\section{Introduction}

Sixty years before Robert E Brown launched his fateful action against the government of the ZAR the Dutch-speaking inhabitants of the Eastern Districts of the Cape Colony (in what is today the north-western region of the Eastern Cape) prepared for a mass exodus from the Cape Colony into the northern and eastern hinterland of southern Africa. This mass exodus came to be called the "Great Trek" and the participants were called the Voortrekkers (pioneers). ${ }^{4}$ These pastoralists and hunters, called Boers (farmers - although the appellation came to denote a cultural class more than it did a designated occupation), had long been disaffected with the British administration of the eastern districts of the colony. Dissension and disaffection with authority came naturally to them. Already in the early seventeenth century their forebears had trekked away from the autocratic rule of the Dutch East India Company and established themselves in the eastern districts. There they engaged in pastoral farming and in hunting, and sought to lead leisurely, isolated, self-regulated lives, subservient only to the dictates of the Bible and of the severe Calvinist theology they espoused. They regarded with suspicion any attempts by the Cape authorities to

3 As reported by Henry Cloete, British Commissioner for Natal, whom she was addressing at a rowdy meeting in Pietermaritzburg on 9 Aug 1843: see Schoeman 1995: 150.

4 Writings on the Great Trek and on the origins and consequences of the Great Trek are legion. I used primarily the following recent sources for this section: Du Toit \& Giliomee 1983: esp at 1018; Giliomee 2003: chs 3-6; Binckes 2013: passim. The latter work is useful because it references many of the vast number of sources on this topic, although it does contain inaccuracies and is aimed at a popular rather than a scholarly readership. Walker 1934: passim, the first comprehensive lone-standing work on the Great Trek, remains a useful source of information. 
exercise control over them, particularly in so far as relationships with the indigenous inhabitants of the region were concerned and in the manner in which they resolved the inevitable conflict between them and the indigenous Xhosa, Khoikhoi and Khoisan. Even the advent of the more democratically-inclined government exercised over the Cape of Good Hope by the short-lived Batavian Republic from 1795-1803 had little impact on the deep-seated desire of these eastern districts Boers to cultivate their own independent, largely pastoral, lifestyles.

With the advent of permanent British rule over the Cape of Good Hope in 1803 and the formal cession by the Netherlands of the Cape to Great Britain in 1814, when it became a British colony, these attitudes, predictably, hardened. With the Cape Dutch they at least shared the same language, the same (Dutch Reformed) religion, the same antecedents. They had very little in common with the British colonial administrators and resented their attempts to impose British law and order. They resented even more liberal British attitudes towards the indigenous inhabitants and the adoption of the policy of egalitarianism implemented by the British authorities.

Gradually, but inexorably, the British imposed their authority on the eastern districts. By the 1820s they had established a measure of stability and order over a region where law had hitherto ruled but precariously. Beyond concerted (and often brutal) military action against the Xhosas, various reform instruments were introduced. The system of land tenure was changed; the administration of justice was reformed; laws were passed for the better and more liberal regulation of master and servant relationships and for a steadier and more secure supply of labour; institutions of government were Anglicised; and principles of free trade were introduced. Underpinning much of the reforms was a concerted effort, one in which the likes of John Philip and other members of the London Missionary Society played no small part, to ensure not only equality before the law between White and Black but also a social equality between the races. These reform measures reached their apogee with the passing of Ordinance 50 of 1828 . This law gave to "Hottentots and other free persons of colour" the same rights and privileges as those enjoyed by white colonists and removed all restrictions on full equality in respect of personal liberty and security of property. ${ }^{5}$

The frontier farmers deeply resented these reforms. They had no desire to experience the British-style Progress of the Enlightenment Era. The reforms introduced into their society notions of equality between White and Black that offended their sense of the divinely-inspired natural order of things. They were passed on the strength of a humanitarian theology that was the antithesis of the theology of racial superiority adopted by the Boers. The laws were poorly administered in the sparsely-populated eastern districts by a British administration in no way adequately resourced to properly implement the changes. The reform measures were imposed on them, there was no consultation with them and they had no means to have their views

5 The text of the ordinance is published in Eybers 1918: 26-28. 
appropriately represented in British decision-making fora. The British officials, with some exceptions, and the missionaries, also with some exceptions, could scarcely contain their contempt for the backwardness, indolence and cruelty of many of the frontier farmers towards the African inhabitants. The frontiersmen, for their part, were convinced that the patronising and supercilious British officials understood little of frontier life and society, imposed foreign rules and practices on them that bore little relation to the realities of their precarious existence and did more harm than good. And through it all, conflict between White and Black raged unabated on the eastern frontier of the colony.

The turmoil of the 1820 s persisted into the 1830s. William Wilberforce's movement for the abolition of slavery gathered pace worldwide in these years. The movement triumphed when an Act was passed by the British Parliament in August 1833 to abolish slavery in its colonies. In the Cape of Good Hope the 39000 slaves in the colony were freed on 1 December 1834 and fully emancipated on 1 December 1838. The institution of slavery had been an essential feature of the way boer society ordered itself and its abolition was an attack on its very core. Increasingly the Dutchspeaking inhabitants of the eastern districts found themselves to be mere fringe participants, in and at times even mere spectators in a frontier society in which their interests were subsumed within a swirling interplay of British interests, political, agrarian, commercial, military, religious and social. The long-simmering tensions between Xhosa and colonist on the eastern frontier erupted into the brutal and bloody Sixth Frontier War in December 1834. Boers fought side by side with the British in this conflict. At the conclusion of the conflict little had been achieved by either side. The Boers still did not have enough land, they had little security of tenure over the land they occupied, payment of compensation they had been promised for damages they had suffered as a result of the war was mired in red-tape and wholly inadequate. To add insult to their sense of injury, the liberal (Whig) Secretary of State for War and the Colonies under Prime Minister Grey, the combative Lord Glenelg, assumed office in April 1835. In July he arranged for the establishment of a Select Committee on Aborigines. Its purpose was to investigate abuses perpetrated by colonists on indigenous peoples in British colonies. Glenelg was strongly influenced by the evidence provided to this committee on the ill-treatment of the Africans and other indigenous inhabitants by colonists in the eastern districts of the Cape Colony (Philip and his co-missionaries being in full voice on this topic). He concluded that the Xhosas had been justified in instigating war against the colonists. He nullified any land gains the colonists had achieved. Once again the Boers felt that their interests had been sacrificed to a cause they neither believed in nor were consulted on.

Disillusioned, insecure and alienated, their cherished freedom severely constrained, the eastern districts Boers had been agitating among themselves for some time already to leave the colony and trek into the southern African hinterland. Buoyed by positive reports from three scouting parties dispatched to all parts of the 
hinterland in 1834 , their leaders decided amongst themselves that it was time to leave the colony permanently. The first trek parties (led by Tregardt - the surname would late morph into the modern form "Trichardt" - and Van Rensburg), some one hundred persons in total, left in the summer of 1835-1836. Their avowed aim was to trek as far north as possible, as far away from British influence as possible, to live their lives as they saw fit, free from British interference, trading with the Portuguese and using their port at Delagoa Bay. In early 1836 many hundreds more began the laborious trek north. One of the trek parties was led by Hendrik Potgieter, a member of the strictly orthodox and fundamentalist Dopper sect of the Dutch Reformed religion. He would become one of the most influential, if most troublesome, of the trekker leaders. He was joined on his way north by the Kruger clan, themselves Doppers, among whom numbered ten-year old Paul Kruger. By the spring of 1837 an estimated 2000 Boer men, women and children, with their servants and livestock had trekked north. They established laagers (defensive camps) beyond the Orange River, in the area today called the Free State Province, where the good life, the just life and the self-determined life beckoned. ${ }^{6}$ By 1840 some 6 000-8 000 Voortrekkers had trekked over the colonial borders (around $20 \%$ of the white population of the eastern districts) and by 1845 the numbers had swollen to some 20000 men, women, children and accompanying servants, occupying huge swathes of territory in the northern and eastern parts of southern Africa.

The famous "Manifesto" of Piet Retief, published in the Grahamstown Journal on 2 February 1837, provided a summary of the political motives for the trek of these Boers (styled the "emigrant farmers") into the interior (for many their motives would have been not so much political as rather the desire for adventure or to rid themselves of poverty or the unwanted attentions of the British authorities). ${ }^{7}$ In a word, they were fed up. Fed up with the administrators, with the missionaries, with the Africans, with the constant struggle for survival in an environment both physically and socially inhospitable, with the felt affronts to their cherished independence, with their treatment by the British as a social underclass. All wished to start a new life beyond the colonial borders where they could be rid of British authority. All were bound by an overwhelming desire to be rid of the British, to be free and independent, to govern themselves, to practise their religious beliefs and engage in "proper" relations with the heathen races unhindered by the missionary-influenced authorities. These motives and desires dominated the trekker psyche, were perpetuated by their descendants and governed the political, social and economic dispensations they crafted for themselves in the decades ahead.

The British authorities did not take kindly to this Great Trek of emigrant farmers, British subjects all, over the borders of the Cape Colony. They had a very real fear that the settlement of these trekkers on land occupied by the indigenous inhabitants

6 See Giliomee 2003: 162.

7 An English translation of Retief's manifesto is published in Eybers 1918: 144-145. 
would cause conflict and that such conflict would spill over into the Colony, to British detriment. In August 1836 the British Parliament passed a law, An Act for the Prevention and Punishment of Offences Committed by His Majesty's Subjects within Certain Territories Adjacent to the Colony of the Cape of Good Hope. ${ }^{8}$ It confirmed the trekkers as British subjects even beyond colonial boundaries and even though they openly rejected their British citizenship. The criminal laws in force in the Colony would apply to all British subjects who committed crimes against inhabitants of territories to the south of the twenty fifth degree of south latitude. The line, only vaguely comprehended in those years, runs roughly through present-day Zeerust, Soshanguve, Mbombela (Nelspruit), Malelane and Xai-Xai (in Mozambique). The line was meant to delimit the sphere of influence Britain arrogated to itself in the southern African region. The rationale for the passing of the law was to protect those who were "in an uncivilised state" in these territories and against whom crimes were often committed with impunity by British subjects (read: the Boers). They would be prosecuted and punished as if their crimes had been committed within the Colony. This law, though poorly executed, would exercise no little influence on future trekker movements and their activities.

It was not only the British authorities that condemned the actions of the Voortrekkers. The Cape Synod of the Dutch Reformed Church, spiritual home to the deeply religious trekkers, also distanced itself from them and tellingly did not provide for an ordained minister to accompany them. Their trek into heathen lands, it declared, away from the spiritual influence of the established church and away from, indeed in flagrant disobedience of the political authority ordained by God, placed their immortal souls in danger. ${ }^{9}$ The Church at the time was under the authority of the State.

By December 1836 some 1800 Voortrekkers were encamped in laagers at or in the vicinity of Thaba 'Nchu, some sixty kilometres east of present-day Bloemfontein, at the foot of the Drakensberg Mountains. It was also where a Methodist mission station had been established in 1833 under the guidance of an English missionary, James Archbell. Some of the more enterprising among them occupied lands further north and west, between the Orange and the Vaal Rivers. Some even ventured beyond the Vaal River. They were able to do so largely as a result of the series of bloody upheavals, called the Mfecane or Difaquane that had taken place in the southern African interior in the 1820 s. One consequence of these tribal wars was that large swathes of territory between the Orange and Vaal Rivers had been denuded of African occupants.

The Voortrekkers' sense of freedom and of well-being did not last long. What the British had feared would happen, indeed happened. Conflict broke out between the Voortrekkers and the Ndebele and a major battle ensued in October 1836. Though

8 The text of the law appears in Eybers 1918: 146-148.

9 See Walker 1934: 129; Giliomee 2003: 162. 
the Voortrekkers managed to repel the Ndebele army, they were badly shaken and only the arrival of a large contingent of Voortrekkers under Gert Maritz prevented the collapse of the enterprise.

Their leaders recognised the necessity for them to organise themselves to ensure not only their protection but also some form of rudimentary governance.

\section{The first instruments of Voortrekker government}

Gert Maritz provided the impetus. He was well-read and had been a man of influence in his home-town of Graaff-Reinet. He was the only Voortrekker to take with him a library of sorts, containing a number of legal and theological works. ${ }^{10}$ Self-assured, he called for a meeting of the people (the volk) at Thaba 'Nchu soon after his arrival.

Undoubtedly Maritz and the other leaders (or at least the better read and therefore more informed among them) were influenced by a political consciousness that had developed among a group of Cape burghers and among rebels in Graaff-Reinet and Swellendam in the eastern districts in the last two decades of the eighteenth century. This consciousness retained its potency for the next generation. These early burghers had styled themselves Cape Patriots after the Dutch Patriots who had influenced the establishment (and later also the fall) of the Batavian Republic in the Netherlands from 1795 to 1806 . The Dutch Patriots in turn had been influenced by the American Patriots who had instigated the American Revolution in the years 1765 to 1783. The Cape Patriots proclaimed the values of freedom, independence, democracy and equality in a republic. Like their Dutch counterparts they rejected the monarchy and the European class system. These concepts were employed by the Cape Patriots largely as slogans to address local concerns and advance local interests, rather than as revolutionary principles. The Cape Patriot movement fizzled out in the mid-1780s when the Dutch Patriot movement in the Netherlands was suppressed. Their ideals and the concepts they used infused the language of the short-lived rebel movements of Graaff-Reinet and Swellendam on the eastern frontier in and around 1795. ${ }^{11}$ Succeeding generations, influenced too by the more liberal attitudes of the Batavian Republic that held sway in the Cape of Good Hope from 1803-1806, adopted these ideals and concepts. Among them were the frontier farmers of the 1830s. They had naturally been strongly influenced by the demands of the eastern frontier rebels for representative government.

The core of their political beliefs was the supremacy of the will of the people - the volkswil. This found expression in the voice of the people - the volkstem. The volkstem was therefore sovereign at all times in all affairs of state, not only during elections. The volkstem, as a metaphysical concept, had an air of majesty to it. It

10 On Maritz see Thom 1947: passim, and on his library holdings on trek see at 116-118.

11 See Giliomee 2003: 72-79. On the Cape Patriot movement see Beyers 1929: passim. 
was, in fact, the shibboleth of the Patriot movement ${ }^{12}$ and would retain its potency for later generations. The descendants of those rebels lived among the disaffected frontier farmers and stoked the fires of resentment. Their fervent desire was to be as free and independent as the Americans were, as the French were - or had briefly been - and as the Dutch had briefly been during the Batavian interlude; to be governed by themselves in accordance with a Rousseau-ean social compact between the governors and the governed; to do so in a maatschappij (a political society) where no class distinctions existed and where the welfare of the volk (the people) was the dominant motif. At the heart of this social compact was an understanding that those who governed were given the right to do so on condition that they exercised their powers for the mutual and coordinated benefit of the governed and were allowed to do so only as long as they exercised their powers beneficially. This became embedded in the consciousness of those whom they influenced, however loosely and dimly understood were the means to translate these desires into effective mechanisms of politics and government. ${ }^{13}$

"The people" - probably some 200 of the men - gathered on 2 December 1836. The minutes of the meeting have been preserved. ${ }^{14}$ Those present, exercising een algemene volkstem (a general voice of the people) elected seven among them to be rechters (judges, that is arbitrators of disputes and makers of rules) in a Collegie ${ }^{15}$ of Lichaam (council). Their election to a governing body obliged them (by swearing an oath to do so) to conform strictly to the laws and rules made from time to time by a general assembly of the people. For their part the Gemeene Mannen, uitmakende het Volk (the commonality of men $^{16}$ - the electorate - comprising the People) solemnly swore to submit faithfully and peacefully to the judgments and commands of the elected rechters. Maritz was elected President and Potgieter Legerkommandant (ie, military commander). ${ }^{17}$

This rudimentary governance arrangement, judging by later events, had little lasting impact. Nevertheless, faint echoes of the political consciousness that was the legacy of the Cape Patriots and the Graaff-Reinet/Swellendam rebels resonate in these rude minutes. Maritz, the man in all likelihood responsible for the first

12 See Beyers 1929: 163, 197-199.

13 See, in general, Wypkema 1949: 38-42; Wypkema 1939: 48-49; Du Toit \& Giliomee 1983: 231242; and Strauss 2008: 64-65. See, too, Giliomee 2003: 54-56.

14 The minutes were first published by Preller 1918: 297-298. See, too, HS Pretorius \& DW Krüger (eds) 1937: 13-14.

15 "Collegie" was a term used in Dutch politics for a governing body, especially in judicial matters. A number of such "collegies" existed in the Cape during the Dutch East India Company period. The use of the term is an indication of a desire among the Voortrekker leaders to distance themselves from British institutions and to return to the Dutch institutions and terminology of the DEIC period.

16 See Preller 1918: 297-298. See, too, Pretorius \& Krüger 1937: 13-14.

17 Thom 1947: 104-106. 
governance arrangement of the trekkers, ${ }^{18}$ was a native of Graaff-Reinet and certainly well-versed in the rebels' cause and the simmering subsequent discontent.

It reflects the first documented use by the trekkers of the notion of a volk ${ }^{19}-\mathrm{a}$ people - in respect of this collective of disaffected pastoralists, who shared farming and hunting interests, a particular lifestyle and cultural habits, the same religion, an aversion for things British and a burning desire to be free and independent. It also reflected the democratic election of representatives of the people to a single governing council. This was an important exhibition of democratic decision-making to replace the non-representative government they had left behind. No separation was (yet) required between the different powers of government. The electoral process was the exercise of the volkstem (the voice of the people). This notion of the vox populi had been adopted by the Voortrekkers from the politics of the Cape Patriots and their political descendants. ${ }^{20}$ Many of the leaders cherished for the collective of trekkers the ideal of a free and just government as it had existed in Holland (and nominally in the Cape) during the period of the Batavian Republic.

The notion of the volkstem, how it was exercised and from whence it derived its authority would become central to constitutional debates in the nascent Boer Republics, in the South African Republic in particular. ${ }^{21}$ The echoes of the debate would still resonate loudly in the 1850 s when the debate on the nature and content of a constitution for the Republic raged and would still resonate in the chambers of Paul Kruger's Volksraad and of Chief Justice Kotzé's Supreme Court in the 1890s as the saga around Robert Brown's challenge to the authority of the Volksraad unfolded.

The minutes also provide evidence of a rudimentary social compact. In terms of this compact the people made the laws and expected their elected governors to faithfully apply them; the people in turn solemnly vowed to uphold the judgments of the governors and not to challenge the manner in which they executed the laws. ${ }^{22}$ Conceivably (although it is perhaps improper to attach such subtlety of political distinction to the arrangement) the assemblage of persons wished, through the exercise of their volkstem, to vest sovereign authority for law-making in the volk and executive authority in the governing council (later to be called the Volksraad). ${ }^{23}$

This social compact would, in later years, give rise to much debate as to who had ultimate, that is, the highest, authority in a state, the volk (the people) or the Volksraad (the council of the people, the government). The question later posed and variously answered was, Wie heeft de Koningstem? (Who has the King's voice?). ${ }^{24}$

18 Idem 119-120.

19 The term volk to designate the collective was borrowed from the Patriot movement of the late eighteenth century: see Beyers 1929: 60-61.

20 See Wypkema 1939: 49; Strauss 2008: 65.

21 On the volkstem and its influence on democratic movements in America, in Europe and in South Africa, see Beyers 1929: 196-201; Wypkema 1939: 38-40, 210-212, 282-317. See, too, Gey van Pittius 1941: 9-13.

22 See, further, Walker 1934: 127; Du Toit \& Giliomee 1983: 244.

23 See, eg, the view expressed by Gey van Pittius 1941: 13.

24 See Wypkema 1939: 49-501; Strauss 2008: 65-66. 
Sixty years later Paul Kruger, in his inaugural address in May 1898 as the fourth State President of the Zuid-Afrikaansche Republiek, singled out this democratic election of a seven-man council at Thaba 'Nchu in December 1836 (his father would have been an active participant) as the birth of the volkstaat (people's state) he so vigorously, if vainly, defended until the very outbreak of war in $1899 .{ }^{25}$ It was this same volkstaat concept that Chief Justice Kotzé sought, as vigorously and as vainly, to transform into a species of modern enlightened constitutional democracy, into a Rechtstaat, foreign to the political conceptions of the volk.

The niceties of democratic governance were soon subsumed under the far more pressing necessity to defend themselves against the Ndebele and to survive in the harsh living conditions they had chosen for themselves. A decisive military victory was achieved over the Ndebele in early 1837 . Soon, though, schism reared its head. Maritz and Potgieter were very different personalities, had very different ideas of how the fledgling society should be governed, and differed also on matters of religious doctrine. Also, they did not much like each other. Typically in such nascent communities, people chose personalities over principles and soon there were Potgieter and Maritz factions. The Potgieter group, desiring to trek as far north as they could, settled in what is today the northern Free State, around the little hamlet of Winburg. Maritz and his followers remained in the Thaba 'Nchu region and prepared to trek east over the Drakensberg into their Promised Land, Natal. Charismatic, educated, born-to-lead Piet Retief and a large group of his followers joined the Voortrekkers at Thaba 'Nchu in April 1837. Immediately upon his arrival elections for the governing council (now called a burgerraad - citizens' council) were held. Retief was elected "Governor", in place of the recalcitrant Potgieter, and Maritz as "President Judge" (ie, head of the council). In his acceptance speech Retief said that in his election through the exercise of the volkstem he recognised the voice of God. This sentiment was clearly inspired by the notion of vox populi vox Dei (the voice of the people is the Voice of God). The actual aphorism is traceable at least to the time of Charlemagne, the sentiment as far back as Homer. It was an aphorism that the Dutch Calvinists had appropriated for themselves in the eighteenth and nineteenth centuries, as had the Dutch Patriots. ${ }^{26}$ Given its combined Calvinist and Patriot lineage it is small wonder that the Voortrekkers and their descendants would appropriate this political concept for themselves as a cornerstone of their governance arrangements.

An attempt was made to patch up differences among the Voortrekkers in June. At a meeting at Winburg on the banks of the Vet River (in Potgieter territory) "Nine Resolutions" were approved by the burgerraad. ${ }^{27}$ In its preamble the burgerraad was enjoined to comply with and to execute the resolutions passed by the people (and to swear to do so). The community of Voortrekkers was now referred to as a

25 See, eg, Van Oordt 1898: 855-856.

26 See Beyers 1929: 199-201; Wypkema 1939: 50-53, 381-382.

27 The text is published in Preller 1918: 300-301. See, too, Pretorius \& Krüger 1937: 14-16. An English translation of these resolutions appears in Du Toit \& Giliomee 1983: 282-283. 
maatschappij (a society), denoting a developing political sensibility. (The Dutch term maatschappij, as employed in that period, meant a community with shared interests, such as the citizenry of a state or the inhabitants of a civic community.) In terms of the second resolution, directives issued and decisions made by the rechters (ie, the council members) in the exercise of their duties and by other civil and religious functionaries appointed either by the volkstem or by the burgerraad had to be obeyed by all upon pain of punishment. Reflected here is the abstract concept of the volkstem (voice of the people) to which all owe obeisance.

The tone of consensus and democratic decision-making through the volkstem embodied in the Nine Resolutions became discordant almost immediately. Retief had too much authority, it was said. He was exercising an arbitrary authority, without reference to the elected leaders of the burgerraad. Maritz warned that they would soon become victims of the same sort of overbearing autocracy that drove them from the Cape Colony in the first place. Not all of the trekkers had had an opportunity to express their opinion, the newcomers complained. Why not wait until the final destination had been reached (Natal, of course, not Potgieter's inhospitable north)? Then only will true freedom and true democracy as practised in the United States of America be achieved. Then only can a true general assembly gather to elect leaders and to frame appropriate laws. ${ }^{28}$

\section{The Republic of Natalia (1839-1843)}

In the summer of 1837-1838 a dispersion of Voortrekkers took place. Some remained where they had initially occupied land, in what is today the southern and eastern Free State; many, with Potgieter, trekked yet further north and, after a decisive victory against the Ndebele in November, settled on the Highveld, on land vacated by the fleeing Ndebele, in what is today the northern Free State and the trans-Vaal area. Among them was the Kruger clan, which included ten-year old Paul Kruger. This would be Potgieter territory and would be ruled by Potgieter and his lieutenants as his Dopper-dominated theocratic fiefdom. Most (joined by yet more recent emigrants from the Cape Colony) trekked with Retief and Maritz over the Drakensberg Mountains to Natal, the land of the Zulus, where they hoped to establish representative, democratic government, living on land they hoped to gain from the Zulu King, Dingane. This dispersion of Voortrekkers was not only a geographical phenomenon - it had political undercurrents too. Those who remained, for example, chose to live in close proximity to the Cape Colony and did not therefore actively disassociate from the Colony. Those who trekked north were the hardliners, almost fanatical in their desire to get as far away from the British as possible. Those who trekked east were, by and large, concerned to establish a republican form of

28 See the (English translation of) texts published in Du Toit \& Giliomee 1983: 184-185. 
government, independent of Britain, but yet close enough to engage with the Colony as an equal partner.

In February 1838 Retief and some one hundred other men were killed at Dingane's kraal at Umgungundhlovu, where Retief signed a treaty with Dingane that they hoped would release land to the Voortrekkers. It ushered in a period of brutal hostilities between the Zulus and the Voortrekkers. When Maritz died in September, the trekkers were without a recognised leader. In the survival mode they found themselves in, there was little inclination to establish republican governance. The tide turned militarily in their favour with the arrival from Graaff-Reinet of Andries Pretorius and a group of fighting men, who had heeded the pleas for military help from the Natal trekkers. A man of wealth and substance and an imposing figure, he was immediately appointed Commandant-General. He organised the Natal Boers (which is how they now came to be styled) into fighting units and, at the Battle of Blood River in December 1838, decisively defeated Dingane, to break the military might of the Zulu nation.

By the end of 1838, the Natal Boers numbered some $3500-4000$ men, women and children. Their largest settlement was Pietermaritzburg and it would become the seat of their government. In June of that year they established an annuallyelected 24-man Volksraad (council of the people), nominally the successor to the burgerraad established at Winburg a year previously. In October 1838 this Volksraad approved a code of governance. Entitled Regulatien en Instructien ${ }^{29}$ ("Regulations and Instructions"), it was loosely based on the Instructions drafted by Governor de Mist for the Raad van Justitie in the Batavian period (1803-1806).$^{30}$ Indeed all of the institutions of government the Natal trekkers established over time took their cue from rules and institutions put in place by Governor De Mist and his officials, copies of which Maritz had brought with him on his trek. ${ }^{31}$ It provided in some detail for the governance arrangements of the fledgling society. Significantly, though a separation was recognised between the judicial powers (exercised by landdrosts (magistrates) and heemraden (assessors)) and the legislative powers of the state, no provision was made for executive power. In fact, no provision at all was made for a "president" or a "governor" as head of state. A chairman was elected for each Volksraad meeting, who, significantly, held office only for that meeting. ${ }^{32}$ The prevailing egalitarian spirit seemingly denied any hierarchical form of government, hence there was no need for a second chamber of government or for an executive head..$^{33}$ The assumption seems to have been that a President, if and when elected (Maritz had occupied the enigmatic position of "President Judge"), would see to the execution of the decisions

29 The text is published, inter alia, in Preller 1918: 303-304.

30 See Preller 1918: 302; Wichmann 1941: 18; Du Toit \& Giliomee 1983: 245.

31 Thom 1947: 118-119; Wypkema 1939: 155, 201-214.

32 See Gey van Pittius 1941: 17.

33 Ibid. 
of the Volksraad and exercise an authority inherent in his person rather than in the position.

Clearly, the authority vested in the Natal Volksraad resided in the fact that its members were representatives of the volk chosen annually by the volk. It patently did not reside in authority exercised on behalf of an absent sovereign. The notion of a social compact no longer featured, not even implicitly.

The Natal Volksraad, which began to meet regularly in Pietermaritzburg from 1839 onwards, had a thankless and a hopeless task. Its members (none more so than the hard-working secretary, JJ Burger) were anxious to impose civilised standards of law and order on a collective of individuals who for the most part resented any such impositions on their farming, hunting and commando activities. But the authority it was able to exert over a society as raw and unsettled as were the Natal Boers, with only a fraction of the resources required to imbue their legislative, administrative and executive endeavours with legitimacy, was always limp-wristed at best. Also, Andries Pretorius, the popular hero of Blood River, the supreme military commander, saw himself, and was seen by many, as the de facto leader of the Boers, often paying mere lip service to the authority of the Volksraad. The soil was yet too barren for true democracy to flourish. The populist volkstem, readily swayed by the most voluble malcontent, often drowned out the voice of reason in the Volksraad and would continue to do so for a long time.

The result was a society in which might often trumped right, unable to create the law and order required to ensure peaceful co-existence with a Zulu nation that had seen large swathes of its territory come into the possession of small numbers of Boers. The constant friction between Boer and Zulu, the constant state of violent turmoil in one or other region of Natal since the arrival of the Boers, did not go unnoticed in the Cape Colony. The British authorities would not tolerate the establishment of an independent Boer entity on its doorstep, especially not one as poorly governed as the "Republic of Natalia", populated by people they still regarded as British citizens and, quite frankly, as inferior. Overtures from the Natal Boers to the colonial authorities for assistance and cooperation fell on deaf ears. If there was to be an European settlement among the Zulus of Natal it would be in accordance with civilised British values, government and laws and British standards of peace-keeping, or not at all.

So Britain slowly increased its military presence in Natal and gradually tightened the political screws on the Natal Boers. By June 1842 it had asserted its military authority in Natal and was mulling a form of self-government for the Boers under British sovereignty. Many among the Boers, tired of the incessant turmoil, were willing to submit. Many, self-styled "patriots", were not. They were buoyed by suggestions planted among them by Dutch traders that the Dutch government could be persuaded to intervene - which of course was never the case. Famously, in August 1843, when the new British Commissioner, Henry Cloete, had gone to Pietermaritzburg to try to pacify the Boers, one of the leading Boer women, Susanna 
Smit, stout of heart and stout of limb, famously shouted at him that the Boers were ready to cross the Drakensberg barefooted and die in liberty, as death was dearer to them than the loss of their freedom. ${ }^{34}$ Finally things came to a head in August 1843. The Volksraad reached a self-governing settlement with Great Britain. Natal was proclaimed a British Protectorate (it was formally annexed as a British Colony in August 1845) in that same month. The Volksraad became a lame duck and finally ceased to function in 1845 .

The Boers had been given the assurance that the British had no immediate designs on the lands in the north, beyond the Drakensberg Mountains, where Hendrik Potgieter held sway. And so again they trekked over the Drakensberg Mountains. Some returned to the Cape Colony, some remained in Natal (Andries Pretorius among them), and some settled in the trans-Orange area, close to the colonial borders. None of these groups was averse to British protection and arm's length oversight. Most, though, trekked to the deep north, to the lands beyond the Vet and the Vaal Rivers, where the towns of Winburg (in the north of today's Free State Province) and Potchefstroom (on the northern banks of the Vaal River) had been established. There they hoped to strengthen their contacts with Dutch traders and philanthropists operating out of the Portuguese harbour at Delagoa Bay.

\title{
22 Governance in the trans-Vaal territory (1844-1852)
}

\author{
“L'etat, c'est moi”: Louis XIV of France (attributed) ${ }^{35}$
}

\section{Introduction}

The trekkers who arrived in the lands beyond the Vet and the Vaal Rivers in 1843 and 1844 settled among Boers who had been living there for some years and who owed fidelity to Hendrik Potgieter. The bond with the Natalians was but tenuous. To be sure, the Natal Volksraad, in a vain attempt to create unity among all members of the trekker maatschappij, had asserted its authority over the lands in the north. Pretorius and Potgieter had declared themselves desirous of such unity. An Adjunkraad (Adjunct Council), a sort of subsidiary of the Natal Volksraad, had been established in Potchefstroom in 1840, whose decisions had to be ratified by the Volksraad in Pietermaritzburg. It was an enterprise doomed to fail, and fail it did, within a year. ${ }^{36}$ Governance arrangements, such as they were, were attended to by a burgerraad headed and totally dominated by Hendrik Potgieter. In 1842 Potgieter pointedly rejected any actions by the Volksraad that could be interpreted as rapprochement

34 See $n 3$ supra.

35 "The state, it is I": attributed to Louis XIV during his address to the Parliament of Paris on 13 April 1655. See Dulaure 1834: 298.

36 On the Adjunct Council and its relationship to the Natal Volksraad see Wichmann 1941: 23-31, $35-36$. 
between it and the British and warned them that any adverse decisions taken on their behalf would be repudiated.

While the Natalians were still trying to integrate into the Potgieter society in the far north, the influx of large numbers of Natal trekkers into the trans-Orange region in 1843-1844, on the colonial doorstep, caused inevitable hostility with the indigenous inhabitants (the Basothos, the Griquas and the Korannas) and threatened the fragile peace that Britain had cultivated with them. Britain intervened and in doing so extended its sphere of influence ever deeper into the northern hinterland.

Hendrik Potgieter recognised the threat to their sacred independence that this extension of British influence posed to Boer independence and the readiness of many Boers to submit to British authority. In April 1844, therefore, he made some important governance arrangements.

He got the burgerraad to declare all burghers of the maatschappij inhabiting land up to the banks of the Orange River (an estimated 12 000) to be free and independent. They repudiated the settlement reached between the Natal Volksraad and Britain in August 1843 and proclaimed that they would not negotiate with Great Britain and would manage their own affairs freely and independently and without hindrance to anyone. Land disputes between them and the indigenous tribes would be settled among themselves.

Also in April 1844 they drafted a set of thirty-three articles to regulate judicial proceedings, what counted as justiciable crimes, the administration of justice and incidental matters in what they called their "Republic". It was called the Drie en Dertig Artikelen, zijnde Algemeene Bepalingen en Wetten voor de Teregtzittingen (Thirty-Three Articles, being General Provisions and Laws for Judicial Proceedings). ${ }^{37}$ The narrow focus on matters judicial rather than administrative or political probably stemmed from an understanding prevalent at the December 1836 Thaba 'Nchu meeting, where the elected councillors were called rechters. This indicated a concentration of effort by the council (councillors were elected annually) on dispute settlement and the issuing of directives rather than on policy-making or administration. The custom of the burghers to submit to the Volksraad petitions and memorials regularly and in large numbers, on issues big and small, for resolution and decision had already become entrenched. This rude document, based on no Cape precedent and no constitution in any sense of the term, ${ }^{38}$ was an attempt by the Boers to regulate their affairs in a civilised manner and to establish a semblance of law and order. In those very early years this attempt would have been as difficult to execute as were the attempts of the Natal Volksraad to enforce law and order in Natal. The long

37 The text is published in Jeppe \& Kotzé 1887: 1-6. On the Thirty-Three Articles see, inter alia, Van der Merwe 1994: passim and, most recently, Wildenboer 2015: passim. The reference to a Republic is contained in art 9.

See Wildenboer 2015: 458-459. 
arm of the law would have struggled to penetrate the vast, sparsely-populated regions of the trans-Vaal where patronage, self-interest and heavy-handedness towards the African inhabitants of the "Republic" would have been a common feature of the society.

Potgieter also recognised the necessity to consolidate his power base to the north and north-east. He visited Delagoa Bay (present-day Maputo) in 1844 (not for the first time), where he met with Dutch traders and sympathisers and with the Portuguese authorities. He took their advice for him to move his seat of operations closer to Delagoa Bay, far away from the British and their sphere of influence and into the Portuguese hinterland. And so it happened that by the end of 1844 a number of Boers established the tiny hamlet of Andries Ohrigstad, 500 kilometres northeast of Potchefstroom, in the fertile, game-rich western foothills of the trans-Vaal Drakensberg. Portugal claimed for itself jurisdiction in the territory north of the twenty sixth degree of south latitude, which line of latitude runs through present-day Midrand in Gauteng and just south of eMalahleni (Witbank). Delagoa Bay lies just north of the twenty sixth degree. As the British claimed criminal jurisdiction in the territory south of the twenty fifth degree of south latitude, British and Portuguese claims to jurisdiction overlapped in a large swathe of territory between the two degrees of latitude. The Portuguese, eager to trade with the Boers, readily granted permission to Potgieter to establish the new location of his government to the west of the hinterland of Delagoa Bay, north of the twenty sixth degree. To be on the safe side they made sure the town was established north of the twenty fifth degree of latitude. ${ }^{39}$

Soon after, in April 1845, conflict erupted in the trans-Orange region of the southern Free State. Boer combatants suffered a humiliating defeat at the hands of combined Griqua and British forces. Much of the southern Free State, as far as Bloemfontein, was now under British control. Many of the Boers there took the oath of allegiance to the British crown. Others trekked north, to the Winburg region and beyond. Britain made it clear that all of the "emigrant farmers" who lived on lands south of the twenty fifth degree of south latitude were deemed to be British citizens and therefore subject to the 1836 Cape of Good Hope Punishment Act. ${ }^{40}$

Potgieter saw the writing on the wall and in the winter of 1845 he and large numbers of supporters joined the earlier settlers in the Orighstad region, conveniently just beyond the twenty fifth degree of south latitude. It would become the new seat of government of the northern trekkers who had already declared their independence in 1844. Also in train were a large group of the Natal Boers, under the leadership of JJ Burger, secretary of the Natal Volksraad, who trekked with them from Potchefstroom to Orighstad.

39 See Wichmann 1941: 45.

40 See $n 8$ supra. 


\section{New governance arrangements in Orighstad}

Just prior to the trek north-east to Andries Ohrigstad, on 6 May 1845, more than one hundred burghers, including Burger and other ex-Natalians, met at Potchefstroom and signed a governance document. ${ }^{41}$ In the document all committed to recognise Hendrik Potgieter as their Commandant-General and Bestierder (Manager/Leader) "for as long as it is deemed necessary". He would, they stated, always have a seat in the Volksraad, to which burghers would be appointed from time to time to govern in accordance with the laws and with his guidance. All who came from elsewhere and enjoyed positions of influence there would submit to Potgieter's authority.

On 30 July of the same year a Volksraad was constituted. It would govern in accordance with the regulations and instructions that had been adopted by the Natal Volksraad (with some revisions as required by the changed circumstances). For Burger and his supporters it was in effect the same Volksraad of the whole Boer maatschappij, originally established in Pietermaritzburg and now transplanted to the more congenial soil of Orighstad. ${ }^{42}$ Now that settled state had been reached, far from the British and close to a harbour and to Dutch support, his leadership was no longer required. As a recognition of past services and of being the only remaining member of the original burgerraad elected at Thaba 'Nchu in 1836, he would remain Commandant-General and be a permanent (non-elected) member of the Volksraad. Since the ultimate authority (the hoogste gezag) in the maatschappij vested in a Volksraad of elected representatives and nowhere else, Potgieter could no longer lay claim to be the Bestierder of the maatschappij. ${ }^{43}$ The style of democratic governance favoured by the trekkers did not provide for a leader (a "President" or a "Governor"). Such leaders, like Retief, Andries Pretorius and, by all accounts, Potgieter himself, arrogated to themselves (and were too readily allowed by a credulous populace) autocratic powers. The notion of hoogste gezag (highest authority) and who in fact exercised it would inform much of the later constitutional debate, re-cast in the form: Wie heeft de Koningstem? (Who has the King's voice?). Potgieter accepted, not with good grace, the arrangement and chaired the Volksraad for upwards of a year.

Down in Natal Andries Pretorius, who had chosen to remain in the newly established Colony to manage his substantial farming and business interests, soon became disillusioned with the generally inept and poorly resourced colonial government. In fact, the complaints of the colonists (Boer and British alike) had the familiar eastern districts ring to them. In August 1847 he went to Grahamstown to meet with the new Governor of the Cape Colony, Henry Pottinger. He first went to the northern Free State, where he knew the Boers there found themselves in a political no-man's land, to drum up support for his confrontation with Pottinger.

41 See Pretorius \& Krüger 1937: 182-184. See, too, Wichmann 1941: 44.

42 See Wichmann 1941: 53-54.

43 See Pretorius \& Krüger 1937: 186-188; Wichmann 1941: 47-49. 
Pottinger snubbed Pretorius and would not even grant him an interview. This highhandedness ignited in Pretorius and others all of the old Boer prejudices against the British. He determined to foment resistance to British rule beyond the borders of the Cape Colony. The spirit of revolution burned brightly in Europe, he said on his campaign trail in the early part of 1848 . He had by then re-located to the Magaliesberg, west of modern Tshwane, where Paul Kruger and his family had established themselves a number of years earlier. People everywhere, he told the Boers, were rising up and seeking to break the shackles of the monarchy and of nonrepresentative government. The Boers must do likewise and become revolutionaries like their equally downtrodden European brethren. Rather face Britain head-on than adopt Potgieter's tactic of simply trekking ever further north and proclaiming independence. Potgieter, wisely, kept his distance in the far north.

Pretorius over-estimated the Boers ' willingness to fight (current Boer governance was not inspirational enough to die for) and under-estimated British military strength. When Harry Smith, Pottinger's successor as Governor of the Cape Colony, proclaimed all of the land between the Vaal and the Orange Rivers to be under the authority of the British crown, war was inevitable. At the Battle of Boomplaats in August 1848 (near where the modern town of Trompsburg lies) Pretorius and his less than enthusiastic Boers were routed in the battle and the Free State Sovereignty was established. Smith placed a price of $£ 2000$ on Pretorius's head. Some of the Free State Boers trekked beyond the Vaal River, to swell the ranks of the Boer population under the nominal governance of the Orighstad Volksraad to around 8000 men, women and children by the end of $1848 .{ }^{44}$

Pretorius established himself on a farm in the Magaliesberg. He continued to cultivate the political support of many in the western and south-western parts of the trans-Vaal region for his crusade for freedom from the British. In a letter written in April 1849 addressed to "true countrymen and friends" he wrote of the hope for freedom which he cherished, that freedom "that surges over the whole world like a sea, but which is dearly bought, as nobody can ever be born without disaster and freedom is a great treasure". ${ }^{45}$ Smith, again, promised not to bother the Boers north of the Vaal too much as long as they behaved as the British citizens they were still considered to be. They could be free, as long as they did not mistake their freedom for independence. ${ }^{46}$ The hoogste gezag, he might have said, belonged to Queen Victoria.

In 1846 the fragile peace that existed between the Potgieter and the Burgerled Volksraad factions was shattered. Potgieter continued to assert himself and to exercise authority (under the guise of military necessity) without seeking the Volksraad's consent. In June 1846 a substantial charge-sheet against him was drafted (conjecturally by Burger), and presented to the Volksraad. The gist of it was that

44 See Binckes 2013: 511.

45 See Pretorius \& Krüger 1937: 381.

46 See Wichmann 1941: 81-83. 
Potgieter had acted like an eenhoofdig bestierder (a one-headed autocratic leader). $\mathrm{He}$ and his supporters could be forgiven for many sins (chief among them being cruel treatment of Africans), but any assertion of autocratic government would be unequivocally rejected. ${ }^{47}$ The end result was that, by the end of 1846, amid much acrimony and threats, two "governments" existed side by side at Ohrigstad, JJ Burger's Volksraad and Hendrik Potgieter's Military Council. ${ }^{48}$ The latter functioned on the basis that in an unsettled frontier society the highest authority had to reside in a strong, no-nonsense leader with military support, rather than in an annually-elected collective of law-makers with no military backing.

Potgieter's "might-is-right" approach and the continued maltreatment of Africans by his followers lost him much support. ${ }^{49}$ The Volksraad gained numerical superiority and was recognised as the sole legitimate (if decidedly feeble) authority for the maatschappij. In the autumn of 1848 he and his supporters left Orighstad and settled in the Soutpansberg region, in the far north, south of the Limpopo River.

In that same year the Orighstad settlement was abandoned. Disease, constant hostility between Boer and African and the dashed hopes of substantial Dutch material, political and cultural assistance had taken its toll. They re-located to Lydenburg (present-day Mashining), some fifty kilometres to the south. Indicative of the state of governance at the time, although the Volksraad thought they had chosen wisely and settled well beyond the dreaded twenty fifth degree of south latitude, they had in fact established the town within the dreaded line, if only just. ${ }^{50}$

\section{Governance in the trans-Vaal region prior to the 1852 Sand River Convention: The Volksraad struggles to assert its authority}

At the beginning of 1849 , then, there were three spheres of political influence in the trans-Vaal area. In the deep north, Hendrik Potgieter and his followers held sway, where might was right, the hunting was good and mere lip service was paid to democratic decision-making. In the north-east, in the newly-established Lydenburg region, the Volksraad carried the torch for democratic, representative governance. Nominally the government of the entire maatschappij, their real influence did not extend much beyond the north-eastern region. The majority of the Boers had settled in the south and south-east, in the Potchefstroom and Magaliesberg regions, closest to civilisation and where the threat of African attack was moderate. It was also the region most under threat from British intervention. Here Andries Pretorius began

47 The charge-sheet is published in Pretorius \& Krüger 1937: 225-228. See, too, at 230, 238, 239 \& 265.

48 On the Potgieter Council see Wichmann 1941: 59.

49 See Giliomee 2003: 170-171.

$50 \quad$ Idem at $43 \mathrm{n} 14$. 
to exercise increasing political influence and to preach the mantra of independence from Britain the loudest.

None of these separate spheres of political influence could claim to exercise the sort of government authority on which substantive law and order was based. The British were following events closely (as were the missionaries of the London Missionary Society, prominent among whom was David Livingstone) and they were not impressed.

A general meeting of the people (the volk) took place in the Magaliesberg in February 1849. Both Pretorius and Potgieter were present, as were representatives of the Orighstad/Lydenburg Volksraad. Harry Smith had proposed to the Boers that they accept British sovereignty over the area and British citizenship, in exchange for freedom from British interference. This was rejected. The meeting served as a rallying call for the Boers to re-assert their independence from the British and to start behaving as a unified, peace-loving, civilised, properly governed people who deserved to be recognised as independent.

A subsequent meeting of the volk was arranged for March 1849 east of presentday Tshwane. Burger and his Volksraad absented themselves, firm in their conviction that the maatschappij should be established north of the twenty sixth degree of south latitude, in "Portuguese territory", and seek their salvation through Dutch trade and Dutch cultural influence via Delagoa Bay. The meeting took the important decision, approved by all (even Potgieter) that a Volksraad would be the highest authority in the land, to which all would be subject. It would never be permitted that any one or more persons would exercise authority higher than that of the Volksraad. These governance gains were severely undermined as a result of personal animosities boiling over. Potgieter felt himself slighted at the meeting, withdrew his consent to a unified Volksraad and returned to the Soutpansberg.

Despite this setback the rest of the leaders persevered and the people agreed to again assemble in May just north of present-day Tshwane, at Derdepoort. The Orighstad/Lydenburg Volksraad was persuaded to participate in unification discussions. Burger died just before the meeting, no doubt deeply disillusioned at the inability of the Volksraad to establish itself, first in Pietermaritzburg and later in Orighstad, as the legitimate highest authority in the Boer maatschappij. In the absence of Potgieter and his people, the meeting made remarkable progress under the chairmanship of Andries Pretorius. ${ }^{51}$ They established a Vereenigde Bond van het geheel maatschappy aan deze zyde de Vaalrivier (United Bond of the Entire Society on This Side of the Vaal River). A Volksraad was constituted comprising six members from Ohrigstad/Lydenburg and fourteen from other regions with Andries Pretorius as chairman. It would meet three times per year, and a commissieraad (executive council) would attend to matters between meetings of the Volksraad. There was no position of head of state. The Thirty-Three Articles drafted at Potchefstroom in 1844

51 The minutes of the meeting are published in Volksraadsnotule I at 99-101. 
was approved as a set of generally-applicable laws by the Volksraad and landdrosts in the different regions were enjoined to distribute copies to government officials such as the field-cornets and commandants. ${ }^{52}$ At the meeting Pretorius, from the chair, made an impassioned plea for unity to the people gathered to witness the proceedings of the Volksraad and to see democracy in action. He pleaded for an end to the constant bickering and factionalism among them and to the insults, slander and penchant for litigation among characters who were remarkably temperamental and vexatious in a society that professed a deep piety and was deeply dependent on one another. ${ }^{53}$

The newly constituted Volksraad met in September near where Lydenburg was soon to be established. Potgieter did not present himself. They ordered him to appear at the next meeting, otherwise he would suffer a blockade of the Soutpansberg region. They applied themselves diligently to the business of government, approving among others the establishment of the town of Lydenburg. Careful to confirm the supreme authority of the Volksraad, the position of Commandant-General (the position held by Potgieter) was abolished during peace-time and landdrosts were ordered to make sure that no agitation for such a position took place in their regions. ${ }^{54}$

Despite the establishment of a functioning Volksraad for the "Entire Society on this Side of the Vaal River" tensions remained. The Volksraad obstinately persisted in the fiction that the border of the "United Bond" should be, not the more obvious Vaal River, but the twenty sixth degree of south latitude (without in fact knowing exactly where the line ran). This caused uncertainty for many living in the south and south-west of the trans-Vaal territory. The refusal to countenance the appointment of an executive head of the society was problematic, because it left the society with no individual who could fulfil the important and necessary function of constant engagement with the British authorities on their doorstep. Also, personal animosities ran deep. Pretorius and Potgieter were barely civil to each other. Since the death of Burger, one Hendrik Bührmann, a competent but abrasive young Hollander who had settled among the Orighstad Boers in 1848, had assumed the ideological leadership of the "Volksraad faction", and had antagonised both leaders in his insistence that there would never be eenhoofdig bestier (autocratic leadership). Absurdly, Bührmann and Pretorius even challenged each other to a duel. ${ }^{55}$ Also, the perennial problem of African tribes hostile to the Boers in their midst and the constant need to arrange for commando's to subdue the tribes exacted a heavy toll on the Volksraad and its precarious resources.

The brittleness of the constitutional fabric began to show. A government of twelve annually-elected good men and true, with a rotating chair, no one more

53 Idem at 385-387.

54 See the minutes of the meeting as published in Volksraadsnotule I at 101-109.

55 See Swart 1963: 32, 41. Duelling was a common enough occurrence for the Volksraad to issue a Government Notice in 1863 prohibiting duelling challenges: see Jeppe \& Kotzé 1887: 147. 
important than the other, serving the best interests of a people who actively involved themselves in popular government through annual elections, boisterous attendance of Volksraad debates and the drafting of a plethora of petitions to the Volksraad on affairs local and regional by an engaged volk, was struggling to assert its authority. The volk lived off the land, they were constantly fearful of attack, they lived by their wits rather than their minds. They struggled to fully appreciate that in that vast territory their self-interest could be beneficially served by such transcendent abstractions as statehood, nationhood and republican democracy. They needed a leader - one like Andries Pretorius, the Hero of Blood River.

In a letter to Pretorius in December 1849 a group of fifty seven Boers from the Winburg region in the northern Free State pleaded with him, the kooning der Emigranten (king of the emigrants), wearer of the crown, to come to their aid against the Basothos and the British. ${ }^{56}$ Pretorius heeded their call, despite the monarchical language. He had unfinished business: This was namely to unite all of the "emigrants" into one free and independent Republic, not only those beyond the Vaal River and certainly not only those who lived beyond the questionable twenty sixth degree of south latitude.

The letter to Pretorius from Boers in the Sovereignty preceded a petition to the Volksraad in early 1850 signed by 168 burgers asking for Pretorius to be instated as Commandant-General to quell the tribal uprisings. At the meeting in Potchefstroom in January the Volksraad called for a plebiscite to determine the appetite of the volk for Pretorius to be appointed Commandant-General. Pretorius resigned his membership of the Volksraad at this meeting, intent on pursuing his calling to lead "his" people (all of his people) to independence. ${ }^{57}$

The plebiscite was instructive: The majority (75\%) had no stomach for a permanent commandant-general, certainly not one intent on interfering in the affairs of the Free State Sovereignty. The authoritarian nature of the position and the potential for dissent it embodied featured as the most pressing concerns (Paul Kruger was a signatory to one of the petitions). ${ }^{58}$

One Adriaan Stander, an ardent Pretorius supporter, one of the four who had been outlawed by Smith after Boomplaats and who had fled the Sovereignty to the Marico district, wrote to Pretorius in August 1850, expressing the views of many. ${ }^{59}$ How could the Volksraad, he asked, decide not to appoint a commandant-general? How could they appoint de Hollander (Bührmann) as secretary of the Volksraad? Clearly, he wrote, the public was geen kooning meer (no longer the king), that is, the volkstem counted for naught and the Volksraad called the shots. He was wrong, of

56 The letter to him appears in Pretorius \& Krüger 1937: 401-403. See, too, Wichmann 1941: 94.

57 See the minutes published in Volksraadsnotule I at 115-120.

58 Many of the petitions (both for and against the question posed in the plebiscite) are published in Volksraadsnotule I at 297-315.

59

See Pretorius \& Krüger 1937: 34. 
course: The volkstem had definitively spoken and the Volksraad had given effect to its expression of will. Not, to be sure, the will of the whole of the volk, in Rousseau's conception of the volonté générale, but of a significant majority.

Pretorius would have been well pleased with unfolding events. The burghers of the Sovereignty called him their kooning in December 1849. Eight months later the good burghers of Marico were bemoaning the fact that the public, who dearly wished him to be the Commandant-General, were no longer kooning, seemingly usurped by an ineffective Volksraad.

The coming months would see the Volksraad yield considerable ground. There was much to-ing and fro-ing on the issue of the commandant-generalship. The issue was causing serious division and disharmony. ${ }^{60}$ In January 1851 the Volksraad chose to appointment four regional commandants-general, rather than to appoint Pretorius as Acting Commandant-General for the whole territory - he would undoubtedly undermine Volksraad authority if given free rein. He was appointed for the Potchefstroom/Magaliesberg region (Hendrik Potgieter was appointed for the Soutpansberg region). All were subject to Volksraad authority and regulation. ${ }^{61}$

As with most political compromises, the decision to regionalise the position of commandant-general and thereby limit Pretorius's powerbase, meant to pacify competing factions, satisfied no-one and had unintended long-term consequences. It confirmed a trend that had been developing for more than a year. This was namely that the regions in which the Volksraad meetings took place were only well attended by those who lived in the region. Correspondingly, they were poorly attended by those who had to travel vast distances over difficult terrain from the other regions. The issues each Volksraad dealt with then tended to be peculiar to the region. When a commandant-general for each region was approved, the region-specificity of government intensified.

The volk, apathetic and in survival mode for the most part, increasingly questioned the efficacy and legitimacy of a de facto regionalised Volksraad. It didn't help either that the Volksraad (under Bührmann's influence) continued to insist that the southern boundary of the territory was the twenty sixth degree of south latitude and that the more obvious choice of boundary, the Vaal River, was a practical line of demarcation only, until the boundary line could be determined with precision. Insistence on the line of latitude in fact cut off a large swathe of territory that included Potchefstroom and Heidelberg, long established towns of the trans-Vaal region. Pretorius was frustrated not only by this obduracy. The regulations for the commandant-generalship (drafted by Bührmann) imposed a straitjacket on the position, requiring Volksraad approval before military action could be undertaken. With no little hubris, Pretorius likened his position to that of the Duke of Wellington (he was the Boer Wellington, was

60 See arts 2-4 of the minutes published in Volksraadsnotule I at 146-147.

61 See Volksraadsnotule II at 4-5 \& 279-281. See, too, Swart 1963: 41-42. 
he not?) who had once complained that he could not conduct a military campaign if all and sundry were giving him orders. ${ }^{62}$ Competing political ideologies further prevented any real unity among the trans-Vaal Boers.

The Lydenburg Volksraad, increasingly making decisions that had legitimacy in the north-eastern region only, remained convinced that the route to their salvation as an independent nation lay with the Netherlands. Their conceptions of statehood were deeply influenced by the constitutional doctrines of the Dutch Patriots of the late eighteenth century (who in turn influenced the Cape Patriots). In particular they attached fundamental importance to the need to give full force and effect to the volkstem, and to the liberal democratic ideals of representative government contained in the Dutch Constitution of 1848. This could never be achieved if Britain held any sway over them. Their commercial welfare, they believed, lay through the good offices of the Portuguese at Delagoa Bay to the Netherlands and other continental European countries and not through the British-controlled harbours of Durban and Cape Town. They wished to shed the English-influenced lifestyle and culture of the Cape Colony and sought instead to attract ministers of religion, teachers and craftsmen from the Netherlands. They presented themselves as Dutch by lineage, by Calvinist religious persuasion, by linguistic relationship and by choice, who happened to live in the southern African interior. Their approach towards the British was therefore to keep the peace with them, steer clear of them as far as possible, not to trust them and to avoid doing anything to antagonize them. ${ }^{63}$ Their problem was that, despite well-intentioned efforts from a number of Hollanders located particularly in Amsterdam, Dutch interest in and enthusiasm for their poor African cousins remained a minority undertaking. Even sympathy was not really widespread. Many among the pious Dutch were unimpressed by reports from the missionary societies about the particularly harsh brand of Calvinist piety practised towards Africans by many of the Boers.

Andries Pretorius and his supporters, on the other hand, practised a Realpolitik. The British were a formidable presence right on their doorstep and it was essential to come to an understanding with them. The politics of engagement was important. Their military might was undoubtedly superior to that of the Boers. But the British had their problems. The Eighth Frontier War on the eastern boundaries of the Cape Colony was in full swing and the brutal and drawn-out hostilities placed a heavy burden on limited British resources. In the Sovereignty the British Resident, Warden, had his hands full. Moeshoeshoe's Basothos were restless and hostile, towards the British, the Boers and other African tribes. In mid-1851 Warden sent a force to suppress them and was roundly beaten. The entire region was as unstable and

62 See the letter written by Pretorius to the Volksraad in February 1851, the reply from the commission council at Lydenburg in the same month and a letter to Pretorius written by Bührmann in May 1851: all published in Volksraadsnotule II at 21-22, 202-204 \& 246-252.

63 See Swart 1963: 43, quoting from a letter written by Bührmann to Pretorius in May 1851. 
insecure as once Natal had been. In London, too, southern African foreign policy changed in 1851 . Whereas a desire to extend British sovereignty beyond the Vaal River was still present at the end of 1850 , the turmoil of 1851 on the eastern colonial frontier and in the Sovereignty changed things. There really was no need to expend unnecessary resources on maintaining British sovereignty over a region that had little commercial value for them and in respect of people - Boer, African and Griqua alike - who, frankly, had even less value for them. Harry Smith's inability to quell the uprisings led to his recall by the Colonial Secretary, Lord Grey, and George Cathcart became the new Governor at the Cape. The policy was now one of appeasement. Two Assistant Commissioners, William Hogge and Charles Owen, were sent to the Sovereignty to report on conditions there. ${ }^{64}$

Hendrik Potgieter and his Soutpansberg supporters were simply contrary. They opposed Pretorius and his designs, because they shared the Lydenburgers' desire to make peace with the British and not to antagonise them and to seek salvation through Delagoa Bay and the Netherlands. They also opposed him because they saw Pretorius as a vain usurper who was claiming authority over territory that Potgieter had opened up with blood and guts and could legitimately claim as his own vast fiefdom, to be dispensed with as he (and not Pretorius) deemed fit. ${ }^{65}$

By the latter half of 1851 the time appeared ripe to engage with Britain. Circumstances adverse to British assertion of supremacy locally and abroad meant that it was propitious for a hard push towards a long-term arrangement with them. The power base had now shifted significantly to the Potchefstroom/Magaliesberg region, at the expense of the other regions. Pretorius, who had campaigned successfully against hostile African tribes in the region, was increasingly treated as a proto-head of state, an eenhoofdig bestierder. He called Volksraad meetings where decisions were taken (in the absence of representatives from Lydenburg and Soutpansberg) to confirm the Vaal River as the southern border of the "United Bond", to approve further military action by Pretorius and to begin formal engagements with the British representatives in the Free State. In fact, acting in direct contravention of previous Volksraad decisions, the September meeting, attended by twenty six-year old Paul Kruger of the Magaliesberg region, was no less than a coup d'état. ${ }^{66}$ Because of the absence of representatives from Lydenburg and Soutpansberg the meeting was inquorate. They therefore, with the consent of the public present, constituted themselves as a military council under the chairmanship of Pretorius. Lydenburg and Soutpansberg were enjoined to explain their absence to a judicial tribunal constituted for this purpose. Until such time the public present relieved the Volksraad of its duties and vested its functions in Pretorius's military council. Pretorius was also authorised to negotiate with British representatives on behalf of the Boer maatschappij.

64 See Wichmann 1941: 104.

65 See, in general, Binckes 2013: 512-517; Giliomee 2003: 170-171.

66 The minutes of the meeting are published in Volksraadnotule II at 232-237. 
It was a personal triumph for Pretorius, achieved through strength of personality and military prowess. Not through respect for the rule of law or for the institutions of representative governance, so pivotal to the conceptions of government of the early pioneers. In this respect he received a pointed note from a government official, a fieldcornet, some three weeks after the meeting.${ }^{67} \mathrm{In}$ it he was berated for his presumption in issuing directives to the Volksraad. Who are you to issue such directives, the writer asks? Is dat die kooningstem? (Do you presume to have the King's voice?). If you believe the King's voice belongs to die Kreygsraats en tegenhoordieg pebliek (the military council and public present) at the meeting of 8 September, then I say to you, they do not have it. I prefer to stay true to the laws made by the Volksraad, for in so doing I will be free. He promptly resigned as field-cornet. Not for nothing did Sir Harry Smith call Pretorius a man of great ability, but lacking in scruples. ${ }^{68}$

To Pretorius's credit, when it became clear that the British were willing to engage with him, he wrote to the Lydenburgers more than once, inviting them to put aside differences in order to present a united front to the British. Paul Kruger, then a field-cornet in Magaliesberg, had also written a letter to the Lydenburg Volksraad (calling it myne Volkraat). He urged them to put aside differences and to re-assert their authority by participating in a preparatory meeting scheduled for January $1852 .{ }^{69}$

The overtures from the likes of Pretorius and Kruger had an effect. A group of delegates from Lydenburg and Potchefstroom met in January in Potchefstroom to help Pretorius prepare for his important engagement with the British representatives, Hogge and Owen (Soutpansberg remained conspicuously absent, Potgieter in any event being incapacitated through injury). Such was the spirit of reconciliation that at this meeting it was agreed that the duly-constituted Volksraad (not Pretorius, not some military council) would remain the hoogst gezag en regerings vorm (highest government authority) in the territory. ${ }^{70}$

Pretorius and his party, with the blessing of the hoogste gezag, negotiated successfully with the British representatives Hogge and Owen on the banks of the Sand River near Winburg. The Sand River Convention was signed on 17 January $1852 .{ }^{71}$ It guaranteed to the Boers north of the Vaal River the right to manage their own affairs and to govern themselves according to their own laws. The threat of the Cape of Good Hope Punishment Act had thus been finally removed, as had been the threat of annexation by Britain.

The Sand River Convention was ratified by the Volksraad at a gathering of the volk at Rustenburg on 16 March 1852. It was, in the words of John Kotzé, the "birth certificate" of the Zuid-Afrikaansche Republiek. ${ }^{72}$ At this gathering there was also

67 Published in Krynauw \& Pretorius 1949: 119.

68 See Wichmann 1941: 106.

69 The letter is published in Volksraadsnotule II at 241-242.

70 The minutes are published in Volksraadsnotule II at 51-52.

71 The text appears in Eybers 1918: 358-359.

72 See Kotzé 1894: 7. 
reconciliation between Pretorius and Potgieter and the Volksraad was re-confirmed as the highest authority in the land. For Pretorius, though the victory was sweet, it was incomplete. His legacy was to have been a unification of all the "emigrant farmers" into a free and independent republic. But Britain would not forego its sovereignty over the area between the Vet and the Vaal Rivers (the Winburg region), fearing loss of British prestige if it were to do so. And Moshoeshoe, the Basotho King, had not been invited to the discussions, despite Pretorius's entreaties that he be invited. Everlasting peace between Boer, Brit and African in a vast territory independently governed by the Boers had been within his grasp. It was not to be. Britain belatedly granted the Orange River Sovereignty its independence through the Bloemfontein Convention of 23 February 1854 . The Sovereignty had clearly become a liability to Great Britain and with the onset of the Crimean War in October 1853 such liabilities could not be afforded. ${ }^{73}$ By then, however, Kooning Andries Pretorius had died.

The Convention had not changed the social, economic and political conditions in the trans-Vaal region - there was no new dawn. Dutch commerce, aid and political protection had proven to be a chimera. The deep suspicion against the British remained ingrained. And, internally, little had changed politically.

\section{The drafting of a Constitution for the Zuid-Afrikaansche Republiek (1852-1858): The people have spoken}

"Wy vernemen dat daar gezegt is dat de publiek de Konengstem is, maar wy vragen
of dat zoo is wanneer het publiek eischt om onregt te doen ...": Petition to Volksraad 11 September $1854^{74}$

\section{Introduction}

The Sand River Convention had brought freedom from British interference, but it had not brought independence. The trans-Vaal Boer society of 1852 (some 15000 20000 men, women and children) was still as divided as ever (despite emotional protestations of conciliation); the leaders remained barely civil to one another and few hatchets were buried (in fact, Pretorius and Bührmann loathed one another); the economic conditions of the country had not improved (had deteriorated, if anything: there was a debilitating drought and widespread disease in 1852); the African tribes in and around the Boer territory remained as hostile as ever; British missionaries openly and repeatedly condemned the Boers, particularly those in the far north (Soutpansberg) and far west (Marico) of the territory, for their ill-treatment of and

73 The text of this convention is published in Eybers 1918: 282-285.

74 "We hear that it is said that the public is the King's voice, but we ask if that is the case if the public demands that injustice be done." The petition is published in Volksraadsnotule III at 228-230. 
trafficking in Africans; and government institutions were still under-resourced and barely legitimate.

What was needed, the Boer leaders recognised, was a new beginning. New beginnings for the pretender republic were best executed within the framework of a Constitution for the State. Andries Pretorius knew this better than most. Within a week after the Sand River Convention had been signed, he had written to Andries Stockenström, former Lieutenant-Governor of the Eastern Districts, with whom Pretorius had maintained a regular correspondence. He sought his advice on, among other things, how to set about drafting a constitution for the territory. Move slowly, was Stockenström's sound advice: Get all of the people involved, consider many alternatives and seek the counsel of someone disinterested and well-versed in these matters to assist in the drafting process. ${ }^{75}$

Wise counsel, no doubt, but socio-economic conditions were not propitious. Hostile African tribes were threatening the safety of the Boers everywhere and concerted military action was the dominant agenda item. Travel was difficult, so Volksraad meetings were seldom quorate. At a meeting in October in Rustenburg a decision was taken to hold over any discussion on "all provisions deemed necessary to serve as ground rules - that is, constitutional rules - for approval and ratification by the public" until there was peace and its was again safe to travel ${ }^{76}$ Factionalism again reared its head, when disputes erupted over where future meetings of the Volksraad were to take place and who was entitled to call them. Barren soil indeed for constitutional discussions. Division was heightened when the first minister of religion for the trans-Vaal Boers, the Hollander, Van der Hoff, was appointed in Potchefstroom through the facilitation of Pretorius, without the Lydenburgers having been consulted. Given the centrality of religion in their lives, this action aggravated existing tensions. Often, in the years ahead, religious differences fuelled political differences.

In December 1852 Hendrik Potgieter died, three days shy of his sixtieth birthday. Though a towering figure in the Boer community during the Great Trek and in the early 1840 s, his particular brand of might-is-right, populist and autocratic leadership belonged to a past age and he had little influence on trans-Vaal politics in the years preceding his death. His successors, though, in the Soutpansberg region, would continue to practise a populist style of politics that would bedevil the constitutional debate for some time.

The Lydenburg Volksraad had been working on a set of regulations for the proper governance and functioning of the Volksraad, incongruously sub-titled Grondwet voor de Volksraad van de Zuid Afrikaansche Republiek (Constitution for the Volksraad of the South African Republic). The Volksraad informed the public that

Art 2 of the minutes published in Volksraadsnotule II at 87. 
these regulations would be discussed at its next meeting in Lydenburg in September 1853.

Before the meeting in September could take place Andries Pretorius died. He had picked up an infection while on yet another commando in the west and died in July 1853 at his farm in the Magaliesberg, aged fifty four. He was the leading Voortrekker of his time. The greatness that he thought was in his grasp was not to be. His grand political design went far beyond the ideal propagated by the insular Lydenburgers of a Dutch dependency operating through Portuguese-controlled Delagoa Bay independent of British influence. It was rather for a fully independent Boer Republic from the Orange to the Limpopo Rivers, invested with all the trappings of civilised and prosperous statehood, occupying its rightful southern African space alongside colonial Britain and allied to powerful and friendly African nations. ${ }^{77}$ This grand design was pursued by his son after his death. However, as events later unfolded in the 1850s and 1860s it became clear that he lacked his father's charisma and political nous and was also constricted by the lingering animus his father had generated among many in his lifetime.

Surprisingly, all regions sent representatives to the September meeting of the Volksraad in Lydenburg and a spirit of conciliation prevailed. The important discussion of the proposed instructions for the Volksraad (Grondwet voor de Volksraad) took place and were approved subject to public comment. ${ }^{78}$ The term grondwet was a misnomer. It was really a charter for the proper conduct of the business of the Volksraad. It did, though, contain a number of important provisions that were to influence later constitutional deliberations.

The Volksraad comprised twelve members (this number could be increased to a maximum of seventy-two depending on the population size) who were elected annually by means of the majority vote of males twenty one years and older resident in the region in which the prospective member was resident. A chairman was chosen at each session of the Volksraad, confirming the egalitarian principle that none was entrusted with an executive function beyond the ambit of the Volksraad meeting. The Volksraad had the sole authority to make laws, issue mandates and take decisions on all matters that affected the Republic. A list was provided of the matters on which it had final authority: "In a word," the section concluded, "to provide all of the input and make all of the rules required for the Republic and to execute such." Laws and decisions approved or made by the Volksraad would have preliminary validity only (except laws and resolutions that brooked no delay) and would only be finally approved and become fully operative at the next Volksraad meeting. This was provided no lawful objections were lodged against such laws or resolutions. Landdrosts and commandants-general could attend Volksraad meetings but only to provide advice and information, if required.

77 See, inter alia, Wichmann 1941: 69 \& 78 and see, too, Binckes 2003: 525-530.

78 The text of the Instructions is published in Volksraadsnotule II at 476-480. See, too, at 163. 
Present in this Volksraad grondwet, therefore, were the familiar democratic principles on the basis of which the trekkers had governed themselves since the late 1830s: Participative government, in which the volkstem was exercised by means of annual elections and by means of referral to the volk for comment on legislation before final approval; non-hierarchical government; the Volksraad as the hoogste gezag; power centralised in one ultimate decision-making body; exclusion from final decision-making of the judicial and the military authority. Importantly, too, no distinction was drawn between "laws" and "resolutions': both enjoyed the authority vested in them by the Volksraad.

Two other important decisions were taken at the meeting. The state would henceforth officially be called De Zuid Afrikaansche Republiek (the South African Republic) and the confirmation of the appointment of MW Pretorius to succeed his father as Commandant-General. ${ }^{79}$

At a Volksraad meeting in Potchefstroom in November a controversial constitutional refinement was introduced. It was decided (subject to public comment) that each of the four regions (styled "colonies" in the minutes) of the Republic (Potchefstroom, Lydenburg, Rustenburg and Soutpansberg) would have three Volksraad members, thus limiting the size of the Volksraad to twelve. For good measure it was confirmed - confirmation was clearly needed - that the Volksraad was the hoogste gezag in the Republic. ${ }^{80}$

\section{The debates, tensions and ineptness that prefaced the constitution-drafting}

With Andries Pretorius no longer there to move things along, very few matters of constitutional significance occurred in 1854. The Orange River Sovereignty was granted its independence from Britain by means of the Bloemfontein Convention in February of that year. Within three weeks of the signing of the Convention, the Free State Republic had adopted a constitution. ${ }^{81}$ The expected natural amalgamation of the two independent Boer entities into one grand Republic, one Pretorius had so passionately desired, did not happen. The Orange Free State coveted their independence and most saw no reason to throw in their lot with the Transvaal. Far removed from the commercial opportunities and civilising influences the British colonies presented, the Transvaal Boers with their quarrelsome leaders and interminable religious disputes were not coveted company. ${ }^{82}$

Christoffel Brand, influential Cape politician, journalist and lawyer and longstanding friend of the Boers, and soon to become the first Speaker of the newly

79 See arts 29-31 of the minutes published in Volksraadsnotule II at 152-154.

80 On these decisions see arts 120-121 in the minutes published in Volksraadsnotule II at 191.

81 The text of the Constitution of the Orange Free State is published in Eybers 1918: 286-296.

82 See Wichmann 1941: 132-140; Van Jaarsveld 1951: 150-151. 
established Cape Legislative Assembly, in a fraternal letter to influential Lydenburg politician, Cornelis Potgieter, urged the Volksraad to appoint two qualified lawyers, one as Chief Justice and the other as Secretary of State, to assist with the essential constitutional, legislative and executive work that lay ahead for the young Republic. ${ }^{83}$ It didn't happen. They had not enough funds to pay their own officials, let alone the funds with which to entice young, qualified, adventurous lawyers.

The Volksraad only met once in 1854 , in June at Rustenburg. The debilitating and morale-sapping state of war that existed on a semi-permanent basis between the Boers and the various African tribes precluded opportunities for refined reflection on affairs of state. At this meeting a discussion took place which, fairly innocuous in itself, nevertheless had far-reaching consequences for the constitutional debate in the coming years.

The decision to limit the Volksraad membership to twelve, taken at Potchefstroom in November 1853, had been subject to public comment. Despite agitated debate on the matter (was it appropriate for the Volksraad to amend its grondwet so soon after its approval?) the Volksraad ratified the decision to limit membership to twelve, on the basis of the majority view of the people, expressed in an opinion poll in which 1000 men participated. ${ }^{84}$

On 11 September 1854 five field-cornets of the Lydenburg region, on behalf of those residing in their respective districts, addressed a petition to the Volksraad. It was concerned primarily with church affairs. In it they also expressed the sentiment that the Volksraad could not possibly have had the authority to approve some of the decisions taken at the June meeting. ${ }^{85}$ They took serious issue with the decision to amend the Volksraad grondwet to limit membership to twelve only. They demanded that the grondwet should remain as it was. There was no sound reason for this amendment, they said: Saving on the cost of some additional members surely could not weigh up against the demise of the entire state - which would happen if laws agreed to were changed willy-nilly. They were particularly aggrieved because they noted that the decision to amend the grondwet was taken on the basis of a majority view expressed by the volk: "Does the majority represent law and justice (de regt en de wet) in this country?", they asked.

They then proceeded to unpack their argument in a manner remarkable for the insight it reflected into constitutional concerns and its distinctly progressive flavour. We mean to ask, they wrote, have the existing laws granted the majority the right to make or amend laws as it suited them, even if they were unjust? We have been told that it has been said that the public has the koningstem (the King's voice). Is this still the case if the public demand to do an injustice, or if a section of the public has been granted the authority to exercise power over another section or to make or amend

83 His letter is published in Volksraadsnotule III at 203-209.

84 See arts 2, 6-16 \& 45-46 of the minutes published in Volksraadsnotule III at 9-11 \& 15.

85 The petition is published in Volksraadsnotule III at 228-230. 
the law to suit them or when they so desire? If that were indeed the case, then surely there would be no need for a Volksraad or for government officials. All matters could simply be referred to a majority vote by the people. The majority then replaces the Law. Surely this cannot be, not when God has in the Good Book commanded us to have law and a government. Surely one section of the public cannot simply exercise power over others that results in domination? The majority cannot simply dominate. We have noted how much punishment and how much injustice have been brought upon mankind by the majority (no doubt a reference to the 1848 European revolutionaries and the Communist Manifesto published by Marx and Engels). We demand merely that law and justice should prevail, never the majority. ${ }^{86}$

This document was preceded by two other Volksraad petitions. On 28 June, after the Volksraad meeting, Commandant-General Piet Potgieter (Hendrik's son and his successor as Commandant-General of Soutpansberg), writing on behalf of the inhabitants of the Soutpansberg, informed the Volksraad that they held the view that any decision taken by the Volksraad which did not carry the general consensus of all (the volonté générale), would have no binding power over "the public under my authority" if it was contrary to their interests. Precisely the sentiment the Lydenburg field-cornets took issue with. ${ }^{87}$

Adriaan Stander, the old ally of Andries Pretorius and a firebrand of note, had caused a stir in the Free State Volksraad (he had returned to the Winburg district, from whence he had originally come and was stoking unification fires) when he petitioned it in September. In his petition he called for the removal from office of the anti-unity President, Josias Hoffman. He asked, with reference to the fact that a large number of Winburg Free Staters were staunch supporters of one united Boer maatschappij: "Does the public have the King's voice, yes or no?" The people should be consulted on the issue before the Volksraad can make the decision (not to consider unity). It was the same stance he had adopted in 1850 when, in a letter, he had lamented that the public was no longer the King. This was clearly the case, he had written then, if the Volksraad chose not to appoint Pretorius Commandant-General, against the wishes of a large section of the public. The Free State Volksraad provided a terse response: The public is King, but the Volksraad represents the King's voice. ${ }^{88}$

From these petitions, and the petition of the Lydenburg field-cornets in particular, ${ }^{89}$ it is possible to extract a number of serious constitutional questions that were in effect posed to the governance authorities: The volkstem was clearly fundamental to the republican democracy espoused by the Boers. But how does it work in practice? Does the Volksraad truly represent the voice of the people? Why then consult with the public, as provided for in the Volksraad grondwet? On what matters should the

See, too, Wypkema 1939: 379.

87 See Wichmann 1941: 152.

88 Idem at 144.

89 The latter petition is published in Volksraadsnotule III: see n 85 supra. 
public be consulted? Surely not on all resolutions it takes? What counts as resolutions that brook no delay? And what if, once consulted, it is apparent - as will almost invariably be the case - that there is no consensus and that in fact many views exist? Does the majority view always sway the Volksraad, as representatives of the people? What if the Volksraad members disagree among themselves? And, asked the fieldcornets with great insight, what if the decision taken by the Volksraad (whether or not based on majority public opinion) was unjust? Who determines what is just and unjust? Surely the ultimate desire of the people is that they should be governed by law and by justice? Surely a law once made and properly consulted should retain its validity and not be subject to constant revision?

Clearly there were men of ability among the field-cornets, mid-level government functionaries responsible for law and order, who literally heard the voice of the people in the daily performance of their duties. Had not another field-cornet in September $1851^{90}$ berated Andries Pretorius for arrogating to himself the koningstem by issuing directives to the Volksraad? And resigned his position because he preferred to stay true to the laws of the Volksraad, "for in doing so I will be free"?

By mid-1855 the state, as an entity, had hit rock bottom. They were rudderless, devoid of the acumen and the resources required to craft for themselves a constitutional dispensation and to establish the essential instruments of democratic government. Two letters, from the Lieutenant-Governor of the Cape, Darling, and from the newly appointed Governor, Sir George Grey, sent to Andries Pretorius and received by MW, his son, had been read out to a military council meeting near Lydenburg in February. Embarrassingly for the anti-British Boers, both expressed fraternal concern for their welfare and offered assistance to the Boers to govern the country and to provide for their spiritual and material welfare. They sent them copies of Cape legislation and administrative arrangements for their use. ${ }^{91}$ Small wonder EB Watermeyer, a member of the first Cape Parliament established in 1854 and later a judge of the Cape Supreme Court, said in a public lecture at that time that "the trek spirit, with its attendant evils, must rate as the Curse of South Africa". ${ }^{92}$

A lengthy reply to the letter Brand had written in January $1854^{93}$ and which had been received only a full year later, had been prepared (by Bührmann) and was approved by the meeting. ${ }^{94}$ Among the many topics covered, pertinent comments were made on the staatsregeling (state structure) of the Republic. There had always been clarity from the earliest times, they wrote, that the Volksraad, elected by the majority vote of the public, was the oppergezag (supreme authority), however poorly this was executed in practice. However, there were others who held the view

90 See $\mathrm{n} 67$ supra.

91 See arts $2 \& 5$ of the minutes published in Volksraadsnotule III at $34 \& 36-37$.

92 Quoted by Kotzé 1894: 3.

93 See at n 80 supra.

94 It is published in Volksraadsnotule III at 330-336. 
that an eenhoofdig bestier (autocratic head) was most appropriate for their society. Still others believed that, although a Volksraad was indispensable, it was necessary that an eenhoofdig oppergezag (autocratic supreme authority) should have the final authority in the state to approve or reject Volksraad business and to guide the Volksraad. Insufficient knowledge of or experience in constitutional affairs meant that these differences never got beyond political arguments and quarrels. We have, they wrote with much pathos, no lawyers or constitutional experts among us to guide us and the best man among us is incapable, not even with the best will in the world, of providing what we need to design the constitutional state we desire and to be truly free, truly able to govern ourselves.

Still the Volksraad plodded on. It met in Rustenburg in June, where no decisions of constitutional significance were taken. They did, though, appoint crude, rude and shrewd Stephanus Schoeman as Commandant-General for Soutpansberg in the place of Piet Potgieter, who had been killed in a battle with the Ndebele in $1854 .{ }^{95} \mathrm{He}$ would have a major, if deleterious, impact on constitution drafting in the years ahead. They also noted, with some pique, the petition of the five Lydenburg field-cornets ${ }^{96}$ and concurred with the view expressed by one of the members that "the Law and the Volksraad were the highest authority, everybody knows this". It would not have occurred to them that a statement that both the law and the Volksraad were the highest authority could be fundamentally contradictory. They considered - although nothing more - a proposal from Schoeman for the establishment of a federal structure in the Republic, in which each regional council and the federal Volksraad would function, not in terms of a constitution, but in terms of de oude wetten, a reference to the Thirty-Three Articles. ${ }^{97}$

Christoffel Brand, long-standing friend of the Boers, had, in May 1855, written another letter in which he had offered his services to them at no cost to help arbitrate differences and to formulate an acceptable constitutional dispensation. Shamefully, there was no consensus in the Volksraad over whether or not to take him up on his offer. He wrote two further letters, repeating his offer. As a result of indifference and miscommunication, he never came. ${ }^{98}$

The next Volksraad meeting took place at Pienaar's River (fifty kilometres north of present-day Tshwane) in September 1855. Divided as never before, influenced by

95 Ferreira 1978, in his comprehensive biography of Schoeman, paints a picture of a man who had natural leadership ability and was popular among men, but who exhibited abrasiveness, shortness of temper and a thin skin, unable to engage in compromise until it was forced upon him: see in particular 379-384.

96 See n 85 supra.

97 On these decisions and discussions, see arts 9-12 \& 169 of the minutes published in Volksraadsnotule III at $43 \& 85$ and see, too, 280-281.

98 See art 163 of the minutes in Volksraadsnotule III at 83-84 and the letters published at 292-293 \& 338-339. See, too, art 57 of the minutes of the September Volksraad meeting published in Volksraadsnotule III at 102-103. See, further, one of Brand's letters at 365-366. 
the inflamed passions of the burghers gathered for the meeting, the volk and their Volksraad were no longer capable of engaging at a level higher than that of personal prejudice and self-interested alliances. The simmering discontent around religious matters now boiled over. Sides were chosen. You were either for the Reverend Van der Hoff and his Transvaal Church and therefore a supporter of MW Pretorius of the Potchefstroom/Magaliesberg region; or you were against Van der Hoff and therefore a supporter of closer ties with the Cape Synod (and by implication with the Cape Colony), as were the Lydenburg Volksraad and the Lydenburg Church Council.

A Lydenburg Commission Council (a commission council was a sub-committee of the Volksraad and functioned as an executive committee) had approved a decision of the Lydenburg Church Council to re-unite with the Cape Synod of the Dutch Reformed Church - in direct contravention of an earlier Volksraad decision for the Transvaal Church to break ties with the Cape Synod. One of the host of charges ${ }^{99}$ - laid by Commandant-General MW Pretorius - before a special court against the commission council members was treason, no less: The Cape Dutch Reformed Church was the state church of the Cape Colony, therefore answerable to the Cape Legislature, in turn subservient to the British Crown. Unification meant subservience to the British Crown. This was consorting with the enemy, a crime specified in the Thirty-Three Articles. The special court was comprised of Pretorius sympathisers only, because the Lydenburg delegation had removed themselves from the toxic atmosphere (the Soutpansbergers did not even bother to attend). The seven were tried in absentia, found guilty and declared unworthy of ever holding office again in the Republic. The sentence was confirmed by the Volksraad. ${ }^{100}$

Predictably, the alienation and bitterness this sentence precipitated had a lasting impact on future constitutional deliberations. You were now either a loyal Pretorius supporter or a fierce Pretorius opponent. The Rustenburg/Magaliesberg and Potchefstroom regions chose the former approach, Lydenburg and Soutpansberg the latter. ${ }^{101}$

Amidst all of this bitter fighting, the Volksraad took a decision that had farreaching consequences. It appointed an eight-man commission to compile een ontwerp van wetten (a draft of laws, that is, fundamental laws) and to present their proposal to het geheele publiek en alle ambtenaren (the whole of the public and all officials) at the next Volksraad meeting in Potchefstroom in November. One of the commission members was Paul Kruger. ${ }^{102}$

99 The comprehensive charge sheet is published in Volksraadsnotule III at 370-377.

100 See arts 53-54 of the minutes of the Pienaar's River meeting published in Volksraadsnotule III at 102.

101 On these church-based disputes see, too, Wichmann 1941: 157-161; Swart 1963: 59-65.

102 See arts $33 \& 68-69$ of the minutes published in Volksraadsnotule III at $99 \& 104$. 


\section{First attempts to draft a constitution amidst large-scale Sturm und Drang}

\section{The Stuart Constitution of 1855}

The commission had less than a month to draft a constitution. They managed to do this. This could only have been possible if some preparatory work had already been done, and if it had been done by someone well versed in constitutional matters. That someone was a Hollander, Jacobus Stuart. He was an Amsterdam businessman who had arrived in the Republic in December 1851 and had befriended, first, Andries Pretorius and later MW Pretorius. He had tried to launch a land settlement scheme for skilled Dutch immigrants to settle in the Republic, which had failed. He had fully identified with the Republican cause (having written a book on the Boers promoting their cause) and, as a man of learning and intelligence, had been a huge asset in the governance and administration of the Republic. He was the secretary or chairperson of the commission and, according to his own account, not one single clause in the draft constitution did not receive his personal attention. Clearly, his was the dominant presence in the drafting process. It has been speculated that he had a French translation of the United States Constitution with him at the time of the drafting. ${ }^{103}$

The volk duly gathered at Potchefstroom on 5 November 1855 (the Lydenburgers were absent). As had become the norm, the Volksraad was not quorate and five additional members had to be hastily elected and sworn in. The main item on the agenda was the draft prepared by the commission. The draft was read out to the public in the morning and in the afternoon the Volksraad and the public were asked to indicate their support for the draft. Tellingly, the Volksraad - supposedly the hoogste gezag - chose to first ask the commandants-general and their military officers to express their views, before it would itself commit to a view. There were only two commandants-general present (MW Pretorius and Stephanus Schoeman, the third, Joubert from Lydenburg, having refused to participate). Pretorius and his military council voted for the draft to be approved and for it to be implemented immediately. Schoeman and his officers voted for a three-month delay to allow the rest of the public an opportunity to comment. In an impassioned atmosphere the Volksraad approved and adopted the so-called Nieuwe Wetten. It instructed that the public be given an opportunity over the next twelve months to voice concerns against any provision. If the concerns were justified, the offending provisions would be amended to better reflect the general welfare of the country and its people. ${ }^{104}$

103 For biographical details on Jacobus Stuart see Dictionary of SA Biography IV sv "Stuart, Jacobus" at 814-816. See, too, Wypkema 1939: 321-328.

104 See introductory comments and arts 3, 5-8 of the minutes of the Potchefstroom Volksraad meeting published in Volksraadsnotule III 106-107. 
The constitution was a monumental effort, given the prevailing conditions in the country. Its dominant characteristic was that "as a whole and in detail [it] bore the imprint of the Voortrekker, whose knowledge and experience were necessarily limited". ${ }^{105}$ It was, in the view of Lord Bryce, "the pure and original product of African conditions", drawing little from the experience of older countries or their models of government. ${ }^{106}$ This latter comment should come with a caveat: The Voortrekkers and their descendants were in fact strongly influenced by the Batavian Constitution and the principles espoused by the Dutch Patriot movement.

It was entitled Nieuwe Wetten voor de Maatschappy der Hollandsche Afrikanen benoorden de Vaal Rivier (New Laws for the Society of Dutch Africans north of the Vaal River) and comprised a Preamble, 327 sections divided into eleven chapters and an Appendix on martial law. ${ }^{107}$ When compared to the concise sixtyone articles of the Free State Constitution, it was a prolix, rambling affair, with statements of fundamental principle interspersed with detailed provisions on any number of mundane, administrative matters. In fact, its title (Nieuwe Wetten voor de Maatschappy) and the statement in the Preamble that its purpose was to make new laws for the society and to incorporate the existing laws in so far as these did not demand improvement, best articulated what the commission had in mind. It was not meant to be a constitution, not in the sense in which the Free State or the United States of America or France or the Netherlands had constitutions. It was meant to be a comprehensive statement of laws to regulate a society that had had little regulation thus far, supplemented by those laws already in existence and fully operational, and in which were incorporated certain fundamental principles constitutive of their statehood.

There are clear indications that the Batavian Constitutions of 1798 and 1815 and the Dutch Constitution of 1848 influenced the structure and style of the Nieuwe Wetten and some of its principles and institutions. ${ }^{108}$ This should not surprise, given the Patriot-inspired democratic principles embraced by the Voortrekkers and the Dutch background of Stuart.

Since the Nieuwe Wetten was the foundation on which future constitutional drafts and the eventual 1858 Grondwet was built, some detail of its provisions is required, with particular reference to the provisions that caused such controversy in later constitutional debates.

Provisions constitutive of the state (thirty-three articles in all) were captured in the first chapter, entitled Algemeene Bepalingen (General Provisions) and in the second chapter, entitled Over de Bescherming en Verdediging van Kerk en Staat (On the Protection and Defence of Church and State). In these articles the volkswil (the

105 See Thompson 1954: 60.

106 See Bryce 1901: 431.

107 The text is published in Volksraadsnotule III at 380-422.

108 On which see, in particular, Wypkema 1939: 332-346. 
will of the people) is expressed loudly and clearly through the volkstem (the voice of the people), thus confirming the primacy of the Patriot- and Batavian-inspired democratic principles adopted by the Voortrekkers. ${ }^{109}$ It is het volk that determines, demands, desires, aspires, prohibits. The form of government was republican and the desire of its people was to be recognised and respected by the civilised world as an independent and free people. The volk demanded the "most comprehensive possible" civil liberties, including the maintenance of its religious beliefs, the right of assembly and the right to press freedom. The volk expected that its obligations would be met, that law and justice would be maintained and acknowledged its subservience to law, order and justice. The volk, though acknowledging its obligation to proselytise the heathens, would not allow gelykstelling (equivalence) between whites and kleurlingen (persons of colour), unless it was convinced that it would cause the Republic no harm. In this latter qualification, audaciously liberal when compared to the crude earlier provisions regarding persons of colour, one also detects the influence of the less-prejudiced Hollander, Stuart.

In a clear and decisive departure from the traditional trekker notion of a single chamber of representative, egalitarian government in which all state power resided, the powers of state were now clearly separated. Again, Stuart's knowledge of the Constitution of the United States, of the Batavian Constitution of 1815 and of the Dutch Constitution of 1848 (and perhaps some behind-the-scenes advice from Brand) seems apparent. ${ }^{110}$ Authority to respectively present and to execute laws was assigned by the volk to a State President and his Staatsraad (State Council), a term adopted from the Batavian Constitution. Legislative authority resided with the Volksraad. It comprised verteenwoordigers of lasthebbers des volks (representatives or mandatories of the people), elected by enfranchised citizens. Its authority to legislate was constrained only to the extent that the volk would be given three months in which to provide comment to the Volksraad, should the people wish to do so. A Krygsraad (Military Council) would uphold law and order. Judicial authority resided with landdrosts, heemraden (assessors) and jurymen and the exercise of justice was left to their judgment and conscience. A seat for the legislative and executive authority would be established in a central location (decided by the Volksraad at its November meeting to be the new town of Pretoria - named after Andries Pretorius - situated next to the Apies River on two farms bought by MW Pretorius for this purpose). ${ }^{111}$

Other sections in the Grondwet provided important additional detail to the statements of principle contained in the General Provisions. For purposes of this discussion the following provisions are pertinent:

111 Art 70 of the minutes published in Volksraadsnotule III at 116. 
A State President was elected by the volk for a renewable period of three years. He was the first and highest official of the state. All officials were subservient to him, except those who exercised judicial authority. These latter were geheel en al vry en onafhankelyk (wholly free and independent). He (or other members of the State Council delegated by him) proposed legislation to the Volksraad, having first informed the public of such draft legislation three months prior to its submission to the Volksraad. Once legislation was approved by the Volksraad, he arranged for its promulgation within two months and implementation within one further month. Only he (with the concurrence of a majority of the State Council) could declare martial law or a state of emergency). He would, "as far as possible", comply with the need expressed by the volk for the state and the church to flourish (in particular by providing for teachers and predikanten - ministers of religion) and for it to be properly defended. He constituted the Volksraad, based on the results of the annual Volksraad elections; he opened and dissolved meetings of the Volksraad; he presented officials to the Volksraad for appointment; he dismissed state officials and filled vacancies; he was responsible for the civil service; he and the State Council were collectively responsible for using state land beneficially; he had the power to mitigate punishments or to pardon offenders, after having sought the advice of the court; he concluded foreign treaties after having sought and gained the approval of the volk to do so; he appointed foreign representatives and he alone corresponded with foreign nations. He was furthermore obliged to account to the Volksraad for his activities and the manner in which he exercised his rights and duties by means of a comprehensive report to the Volksraad every year in September.

The State Council, the executive council of the state, comprised the State President, the Deputy State President (like the President, elected by the volk), two enfranchised citizens and a Secretary of State (all elected by the Volksraad). They were elected for varying terms of office.

The Volksraad comprised a minimum of twelve members. They had to be members of the Transvaal Dutch Reformed Church, between the ages of thirty and sixty, landowners, not related to one another and had to be of pure blood unto the fifth generation. They were elected by majority vote for a two-year period (special provision was made for a three-year transitional period for the Volksraad). A chairman was chosen by the members from among them for a one-year period. Volksraad sessions were to be held in public, unless the chairman or the State President decided otherwise. A member of the public could speak only when spoken to by the chairman. No legislative draft would be presented to the Volksraad unless it had been presented to the public three months beforehand. If the three-month public notification phase was not adhered to, the State President would investigate the oversight and fine the errant official responsible. In the event that the annual budget or any other law the approval of which brooked no delay, was not approved by the Volksraad, a revised law (or budget) would be presented to a United Council. This council would comprise 
the State Council, the Volksraad and the Commandant-General and was chaired by the Volksraad chairman. Each member had an equal vote, and the chairman had a casting vote.

Crucially, no provision was made, as in the 1854 Free State Constitution, for a special procedure to amend the Nieuwe Wetten. It was therefore like any other law, subject to amendment at the will of the Volksraad. The absence of such a special procedure made it, in the language of Lord Bryce, a "flexible" rather than a "rigid" constitution. ${ }^{112}$ The influence of the Batavian Constitution of 1798 has been posited as a reason for this approach. ${ }^{113}$ It reflected the dominance of the volkstem. This meant in practice that the volk was sovereign, it would not bind itself to legislative immutability, nor would it surrender its sovereignty to a Volksraad or to a Constitution. In the United States Constitution, thus ran the argument, the people gave up their sovereignty in favour of a carefully crafted Constitution. This the Boers would never do.

The judicial authority resided in landdrosts, heemraden (assessors) and jurymen, assisted by registrars, court messengers and, when required, by commandants and field-cornets. The landdrosts and heemraden were elected by majority vote of the inhabitants of the four regions. They had to be members of the Transvaal Dutch Reformed Church, at least twenty five years old and not be engaged in commercial activity. For each region a hierarchy of courts existed. A right of appeal was provided for. There was no "high court" or "supreme court", therefore. The appointments were made by the Volksraad upon the recommendation of the State President. All entrusted with the exercise of judicial authority were "wholly free and independent".

Elections took place at the Potchefstroom meeting for all of the office bearers. MW Pretorius was duly elected State President. ${ }^{114}$

Within a week things began to unravel. Bowing to pressure from Schoeman and his supporters (Schoeman, deeply distrustful of Pretorius, had his sights set on the Presidency) the Volksraad revisited its earlier approval of the Nieuwe Wetten and now declared that it would only be implemented after a three-month period during which the public were to become acquainted with its provisions. Another election of State President and Commandant-General would then take place. Indecision ran rampant.

This ushered in a period of intrigue and plotting between Pretorius supporters, Schoeman supporters and the people from Lydenburg (with Bührmann in the thick of things), who felt themselves wholly excluded from the constitutional debate as a result of the events at Pienaar's River some months earlier. When the Volksraad met at Rustenburg in March 1856 the tensions between the factions had not yet

112 See Bryce 1901: 449-455, esp 453-454. On the distinction between "rigid" and "flexible" constitutions see 150-159.

113 See Wypkema 1939: 342, 344.

114 See arts $9 \& 47-48$ of the minutes published in Volksraadsnotule III at 107-108 \& 112. 
dissipated. Once again the Volksraad proved feckless. ${ }^{115}$ The sentences imposed on the Lydenburg burgers by the special court in September 1855 constituted an absolute bar to any constitutional progress being made. No one was able to break the deadlock, despite earnest attempts by the three commandants-general to mediate the differences.

\section{The Pretorius/Schoeman Constitution of 1856}

Pretorius and Schoeman met a month later to try to regenerate a system of government that had gone into terminal decline. They called for a meeting of the Volksraad in the new town of Pretoria in May to produce a second draft of a set of fundamental laws afresh, based on certain principles that they proposed.

The following were among the principles they agreed upon: ${ }^{116}$ (1) The Volksraad was the hoogste gezag in the Republic and functioned only as a legislative body. (2) The volk would be given a three-month period in which to comment on a proposed law before it was implemented. (3) Volksraad members would be elected by national majority vote and not regional majority vote. (4) Judicial authority would vest in landdrosts, heemraden and jurymen and they would exercise their authority in accordance with their judgement and conscience. (5) There should be an executive authority (a Staatsraad) to implement the decisions of the Volksraad and serve as the government when the Volksraad was not in session. This State Council proposed laws to the Volksraad and, among other functions, made temporary appointments to be ratified by the Volksraad. In cases of danger or of emergency the State Council took provisional decisions, subject to its accountability to the Volksraad.

The Volksraad duly met in Pretoria in May. ${ }^{117}$ One of its members was Paul Kruger, now clearly at the heart of the constitutional process. Jacobus Stuart's services were not required and in fact he would play no further part in the constitutional deliberations. Using the 1855 Stuart draft as their discussion document and guided by the Pretorius/Schoeman principles, they produced a draft (which they simply called a Wet - a Law) within four days. It was a much truncated version of the Stuart draft and included some important revisions:

The Volksraad would comprise twelve members, no more no less, appointed by the whole volk for a renewable three-year period (not two years). It was the hoogste gezag des lands and also the legislative authority. Its powers were, among others, to make laws, issue directives and to regulate and generally to create such institutions and state such requirements as the Republic needed.

A subtle shift is discernible here. The chapter on the Volksraad now follows directly after the General Provisions chapter and not after the chapter on the executive authority as in the 1855 draft. The Volksraad would have a fixed number

115 The minutes of the Rustenburg meeting are published in Volksraadsnotule III at 123-133.

116 See documents published in Volksraadsnotule III at 433-434 \& 434-435.

117 The minutes are published in Volksraadsnotule III at 134-144. 
of seats (twelve, not "a minimum of twelve" or twenty four or "up to seventy two") and its members appointed for three years, rather than annually or biennially. Reference in the introductory "General Provisions" chapter of the 1855 draft to their "representative or mandatory" role was now replaced by a statement that this small group of men with extended periods of membership would be the highest authority in the state and also have legislative authority.

In terms of this draft, then, the Volksraad would no longer be the handmaiden of the volk, in a system where continued individual membership was dependent on the ability of a member to faithfully represent the ebb and flow of vacillating popular sentiment. The immediacy of the influence the volk had thus far been able to exercise over the Volksraad members and their decision-making had now been replaced by an arm's length mandate to govern. The members would now be respected burghers chosen to do a job, which was to govern the country on behalf of the volk and to make laws (subject to an opportunity granted to the volk for a three-month period to comment on proposed legislation).

If the question, Wie heeft de Koningstem? were to have been posed to this commission council by one such as Adriaan Stander, the answer would probably have been that the Volksraad, and no longer the volk, was the King's voice.

Executive authority resided in a Staats Generaal (State General), not in a State President. The latter was the hoogste ambtenaar (highest official, not the highest authority), to whom all other officials (except judicial officers) were subservient. He was elected by the volk for a five-year period and was expected to report annually to the Volksraad on the manner in which he executed his functions. Other members of the State General was a State Secretary appointed by the Volksraad, the landdrost of Pretoria (the official seat of government) and two "unofficial" members elected by the Volksraad.

The expectation that this exercise would bear fruit was misplaced. ${ }^{118}$ Conditions in the country at that time were miserable. Drought and disease was again pervasive, and the continued and widespread hostility of the African tribes demanded concerted military campaigns and the enlistment of burghers increasingly unwilling to go on extended commandos. Schoeman, maverick that he was, distanced himself from the Pretoria deliberations. He informed Pretorius that he rejected the proposed new Law, had always rejected any Pretorius-inspired constitutional efforts and would continue to do so. The Lydenburgers, being absent from the deliberations, attached no legitimacy to the Pretoria efforts. In fact, Lydenburg had exhausted its patience with the constant usurpation by the Potchefstroom and Rustenburg/Magaliesberg regions of state governance responsibilities that rightfully belonged to a Volksraad of which the Lydenburgers deemed themselves to be the legitimate curators. Instigated

118 On the following see, in particular, Wichmann 1941: 166-175; Ferreira 1978: 74-76. 
by Bührmann, they declared themselves independent from the rest of the Republic. ${ }^{119}$ Schoeman applauded them from afar.

Paul Kruger, then in the prime of life, would have been a witness to and a participant in these interminable displays of disputation and contrariness and well knew the damage to progress and good government they caused. Small wonder, then, when he was State President of the Republic many years later, that he would insist upon the necessity for consensus-seeking, consultation and the dissolution of opposition among the volk. He did this to the point where his demands that no opposition should exist to a proposed measure became as stultifying as was the incessant bickering of the $1850 \mathrm{~s}$.

\section{The Pretorius Constitution of January 1857}

MW Pretorius now began to exhibit some statesmanship. He called for a meeting of the volk in December 1856 in Potchefstroom. The aim was to discuss a constitution for the Republic at which all were present, Lydenburg included. Lydenburg refused to participate. It would be a rubber-stamp exercise and Pretorius would become an eenhoofdig bestierder (autocrat) - they clearly hadn't studied the Pretoria proposals very carefully. Schoeman rejected the whole exercise. Nevertheless - and to his credit - Pretorius persisted. A twenty-three-person committee that included MW Pretorius was appointed with the brief "to increase and to improve the Laws of this country where this is deemed necessary". Paul Kruger was not a member.

They completed their work on 5 January 1857 . The introduction to the document stated that additional reasons for the drafting of the Laws were the need to state authoritatively what the country's maatschappelyke beginselen (societal principles) were and to strengthen the bond of unity between the burghers. In a postscript they refer for the first time in an official document to their labours as a "Constitutie". This was almost an afterthought, as the document itself had no heading. Clearly what started off as a compendium or codification of laws, underpinned by general societal principles, came latterly to be called a constitution. There was then no thought that it was a constitutive and immutable document, which is the status Chief Justice John Kotzé sought to attach to it forty years later.

The committee used as its reference document Stuart's 1855 Nieuwe Wetten (the Stuart Constitution of 1855), both in form and in substance, not the 1856 Pretorius/Schoeman revision. In particular, and importantly, in the draft Constitutie the committee retained in all material respects the fundamental provisions of the Algemeene Bepalingen of the Nieuwe Wetten. It used a fine tooth comb on the Nieuwe Wetten, refining, re-formulating, amending, inserting, to produce an improved version

119 On the Lydenburg declaration of independence see, inter alia, Wichmann 1941: 166-175; Swart 1963: 63-65; and Ferreira 1978: 76-78. 
of the earlier draft. ${ }^{120}$ Pertinent were the following provisions: (1) The chief executive officer was to be called a "President" and his council an "Executive Authority". His powers and functions remained largely the same as provided for in the 1855 Nieuwe Wetten, which is to say they were extensive, but subject to Volksraad accountability. (2) Provisions in respect of the Volksraad remained unchanged from the Nieuwe Wetten. Its members (a minimum of twelve) were "representatives or mandatories" of the volk, elected for a period of two years to make laws, the drafts of which were first to be published for public comment - and the officials punished who neglected their duties to properly disseminate the draft laws to the volk. None of the revisions suggested in the 1856 Pretoria draft were incorporated: No reference to the Volksraad as the hoogste gezag; no detailed description of its functions other than law-making; no three-year term; no ultimate appeal authority in judicial affairs. The King's voice once more belonged to the volk, not the Volksraad. (3) Judicial authority remained with landdrosts, heemraden and jurymen. They were to exercise their authority to apply "the prescribed laws" (this phrase being a new addition to the Nieuwe Wetten provisions) in accordance with their judgement and conscience. A hoog-geregtshof (high court) was introduced and its decisions were deemed to be "final and decisive". The guarantee of freedom and independence of judicial officers was retained. Typical of the unstructured and inelegant approach adopted by the committee, reference is made to a Staats Procureur (State Attorney) but the office and its functions were nowhere defined. Upon the recommendation of Christoffel Brand a young Hollander, Proes, was appointed State Attorney in May 1859, having acted for some months previously. ${ }^{121}$ Its beginnings were inauspicious and the office of State Attorney became a demanding and thankless, poorly-paid position. In the first decade of its existence there were no less than ten State Attorneys.

The volk present at Potchefstroom duly approved the Constitutie. They also appointed MW Pretorius as President and Schoeman as Commandant-General (an appointment he rejected out of hand) and inaugurated Pretorius in ceremonial fashion, hoisting the newly-designed national flag. They continued to treat Lydenburg as part of the Republic.

Laudable though Pretorius's efforts were to try to bring order, structure and finality to a constitution-making process that had dragged on interminably, he should have known that men like Schoeman and Bührmann and their supporters would never accept the indecent haste and regional bias by means of which matters had been concluded. They didn't. The Boer psyche of the time lacked the elevated capacity (or the will) for seeking common ground, for give and take and for compromise, for discrimination between persona and res, between the man and the office.

120 The Constitutie, as published in the Government Gazette of 16 October 1857, is published in Volksraadsnotule III at 439-471.

121 See communication from Pretorius to the Volksraad, published in Volksraadsnotule IV at 242. 
The sincere, if crude, attempts in the Pretorius Constitution to create a clear yet functional separation of the powers of state, to achieve a balance between the competing claims for the koningstem - the sovereign voice - made by the People, the People's Assembly and the Chief Executive, were unappreciated or underappreciated. If the Volksraad was not, demonstrably and unequivocally, the hoogste gezag, the constitution gave free reign both to eenhoofdig bestier and to populist sentiment expressed in a regionally-biased majority view. Thus argued Bührmann on behalf of Lydenburg. If Pretorius was the driving force behind the committee's work at Potchefstroom, then he was entrenching a dictatorship for himself. He was behaving, like Louis XIV, as if l'etat, c'est moi. Thus argued Schoeman on behalf of Soutpansberg. And MW Pretorius lacked his father's ability for decisive and critical engagement on the essential details.

Emotions reached fever pitch in the following months and left little room for common sense. Schoeman denounced the entire Constitutie-drafting affair as an exercise in the glorification of Pretorius. He was not averse to war talk, which led to the Soutpansberg being blockaded and to Paul Kruger arguing that arms should be taken up against the "rebel" Schoeman. ${ }^{122}$ Pretorius, in those times of strife, urged on by his supporters, saw fit to try to insinuate himself into Free State affairs and to force the thorny issue of unification. Predictably, his clumsy attempts were rejected and his reputation suffered. ${ }^{123}$ Bührmann, combative as ever and campaigning on behalf of Schoeman (Lydenburg being nominally independent) in the Suikerbosrand (Heidelberg) district against Pretorius and the Constitutie, was arrested for stirring up discontent among the gullible burghers. When informed of this, Schoeman challenged Pretorius to a duel: Whoever succumbs, he exclaimed, will have suffered God's justice and will have been shown up as the perpetrator of injustice. Pretorius, absent in Natal at the time, did not respond. ${ }^{124}$

This theatre of the absurd continued without interruption. ${ }^{125}$ The Lydenburg and Soutpansberg factions sought and obtained the assistance of Free State President Boshoff to diminish the power of Pretorius, the "arrogant autocrat". Things got so out of hand that two groups of burghers, pro- and anti-Pretorius (Paul Kruger being in the thick of things as a Pretorius supporter), confronted each other on opposite sides of the Renoster River just south of the Vaal. Hostilities were called off by the burghers themselves when they realised that no one knew who had started it all and what it was they were fighting for. Peace was declared. All were relieved, except Schoeman, who had been spoiling for a fight.

122 Schoeman's (and his supporters') reaction to the Constitutie and subsequent behaviour is described in detail by Ferreira 1978: 78-82; see, too, Wichmann 1941: 176-177.

123 On Pretorius's foray into Free State affairs see, in particular, Van Jaarsveld 1951: 143-168; see, also, Wichmann 1941: 177-179; Ferreira 1978: 82-89.

124 On these events see Wichmann 1941: 179; Swart 1963: 66-67; Ferreira 1978: 85-89.

125 On subsequent events see, in particular, Van Jaarsveld 1978: 169-208; see, too, Ferreira 1978: 89113. 
After much to-ing and fro-ing and flexing of muscles between the representatives of Pretorius and Schoeman the two parties eventually reached agreement on 1 July 1857 that their grievances would be submitted to a judicial tribunal (comprising six from each side) for arbitration. At this time a petition to Pretorius and his executive from disgruntled burghers pointedly reminded them that in a Republic the collective of the burghers were koning and owners of the land, not individuals nursing grievances. ${ }^{126}$

\section{The ratified Pretorius Constitution of September 1857}

A semblance of calm having been restored, the Volksraad met at Rustenburg in early September 1857, without, though, any representation from Lydenburg and Soutpansberg. ${ }^{127}$ It considered the Constitutie, approved it and directed that the entire text be published in the Government Gazette for the general approval of the public, which was duly done in October. ${ }^{128}$ It ratified the appointments of the President and the other members of the Executive Council made in Potchefstroom in January. The Volksraad also demonstrated at this meeting the flexible attitude they and the volk adopted towards the Constitutie. This was namely to treat it as a law like any other, susceptible to amendment, even to being amended the very next day after it had been solemnly approved (Pretorius having proposed a number of amendments). Urged by Pretorius, the Volksraad was also at pains to try to make peace with Soutpansberg and Lydenburg. They were invited to a gathering of the volk at Rustenburg in November to resolve all grievances and to promote unity. A deputation (among whom was Paul Kruger) would visit these regions to urge attendance upon them.

Despite public statements that they would never submit to Pretorius's dominion, and despite their nominal "independence", a Lydenburg delegation led by Bührmann went to Potchefstroom to meet with Pretorius and his executive. Schoeman, meanwhile, was preparing his charge-sheet against Pretorius for presentation to the agreed-upon special tribunal, and stockpiling arms and ammunition.

The meeting between the Lydenburg delegation and Pretorius proved cordial and fruitful. Although the eventual unification of Lydenburg and the Republic only happened some thirty months later, it facilitated the smoothing-over of differences in political and religious affairs. An important constitutional principle was also discussed and agreement on it reached. Lydenburg had namely objected to the perception created by Pretorius and his supporters that the King's voice (the koningstem) resided with

126 See Wypkema 1939: 378.

127 The minutes are published in Volksraadsnotule III at 150-156, extracted from the Government Gazette of 25 Sep 1857.

128 The publication of a Government Gazette had been approved by the Volksraad in Sep 1857: see art 22 of the minutes of the Sep 1857 Volksraad meeting published in Volksraadsnotule III at 155. 
the majority view of the populace. Of course, Pretorius held sway over two large, populous and (compared to the others) relatively prosperous regions of the Republic (Potchefstroom and Rustenburg as well as parts of the Marico district). Therefore, whenever the Volksraad met in these regions (which was increasingly often) the majority of the volk present would invariably support Pretorius's views. The parties agreed, in language redolent of the petition of the five Lydenburg field-cornets in 1854 , that wet en regt in vervolg alleen regeeren zoude (law and justice alone would govern in future). What they meant was that ultimate authority for governing the country would reside in that body ultimately responsible for law and justice, namely the Volksraad comprising elected representatives of the people. This body would not be dictated to by a majority vote but would take into account all views expressed and govern as dictated by law and justice. Classic "Volksraad as hoogste gezag" doctrine, therefore. ${ }^{129}$

\section{A Grondwet (Constitution) for the Republic is finally approved}

The volk eventually gathered at Rustenburg in mid-January 1858 . The main attraction was the showdown between Schoeman and Pretorius. ${ }^{130}$ Schoeman arrived with eighty armed men and Paul Kruger, on Pretorius's behalf, stood ready to resist. The judicial tribunal was constituted and proceedings began before an excitable public on 25 January 1858.

It was a sorry affair. It dragged on and on, progress impeded by trivialities and one-upmanship. In due course, on 1 February, a whole week later, the court, having convinced themselves that whatever decision they made, whether in favour of Pretorius or of Schoeman, would be rejected by one portion of the public, passed no judgement and disbanded.

Confronted with such spinelessness Pretorius and Schoeman, commendably, took matters into their own hands. On the next day their respective military councils met, twenty-five representing Pretorius (Paul Kruger's name was listed second, indicating his prominence) and fourteen representing Schoeman. ${ }^{131}$ They decided that each party would nominate six members, to be approved by the general public, to form a committee with Pretorius and Schoeman. The committee's mandate was uit alle bestaande landswetten eene Algemeene landswet te zullen maken (to draft a General National Law out of all the existing national laws). Actions and statements made by one party against the other would be retracted and deemed never to have taken place or made (this included the abortive judicial process of late January).

Important instructions were given to the commission council: In the Algemeene landswet the Volksraad would be acknowledged as the hoogste gezag and no laws

129 See Wichmann 1941: 217-218.

130 Idem at 218-220; and see, in particular, Ferreira 1978: 114-118.

131 The minutes of the meeting are published in Volksraadsnotule III at 493-496. 
would be valid unless approved by the Volksraad, but only after consultation with the public. The President would, after the landswet had been approved, exercise his duties in accordance with approved instructions. In the Algemeene landswet the Commandant-General would be acknowledged as a member (full voting member) of the Executive Council (the subservient role of the Commandant-General had been a major sticking point for Schoeman); only the Volksraad could dismiss him from office; and in time of war he took instruction from the Executive Council, except where martial law was declared. In effect, therefore, the Commandant-General would not be subservient to the President (Pretorius). Described by a late nineteenthcentury commentator as an eenigsins boertige (somewhat crude) solution ${ }^{132}$ to a problem of constitutional principle, it did pave the way for conciliation between Pretorius and Schoeman.

Once the committee had completed its task (it was to begin on the next day and continue until the work had been completed) the new law would be implemented immediately. It would also, though, be published for the public's information and comment and be presented to the Volksraad for approval (even though it had by then already been approved and implemented). Such a Volksraad would comprise twelve members appointed by Pretorius and twelve by Schoeman.

The decision of the combined military councils was presented to the public that same afternoon and the drafting committee constituted. It met from 3 to 13 February in the office of the landdrost of Rustenburg. Among the members counted Paul Kruger, Hendrik Bührmann and Cornelis Potgieter (the latter two representing Schoeman, not the "independent" Lydenburg). William Robinson was chosen as chairman. He was born on a British Settler ship and had thrown in his lot with the Boers, accompanying them on the Great Trek and becoming a close friend of Paul Kruger. ${ }^{133}$

The committee used the Pretorius Constitution of September 1857 as their source document (in turn based on the Stuart Constitution of 1855). ${ }^{134}$ They gave it a name: Grondwet der Zuid-Afrikaansche Republiek (Constitution of the South African Republic). For days on end they waded through the Constitutie, revising, adjusting, removing, re-arranging and inserting the clauses, those called for by the combined military councils and otherwise those required in the spirit of compromise on matters of principle both big and small. Despite calling it a Grondwet - a fundamental law they did not make provision for its amendment or revision by special procedure, as was the case with the Free State Constitution. For them it was a law like any other,

132 See Ferreira 1978: 121, quoting Frans Engelenburg, who was editor of the influential progovernment newspaper De Volkstem in the 1880s and 1890s.

133 See Dictionary of SA Biography vol IV sv "Robinson, William" at 541-542.

134 The minutes of the meeting of the drafting committee are published in Volksraadsnotule III (n 72) at $159-163$. 
a very comprehensive and important law, but a law conceptually no higher than any law.

They had decided to achieve consensus on all of their deliberations and this they managed to do. In the prevailing atmosphere this was no mean achievement. A four-man sub-committee was appointed to present the 232-article Grondwet to the Volksraad. One of them was Paul Kruger. There can be little doubt that Kruger had been at the coalface of the constitutional deliberations since 1855, was privy to and participant in all of the convoluted arguments and disputes and that he played a prominent role in the deliberations.

The Volksraad duly met on 16 February $1858 .{ }^{135}$ The Grondwet was approved by the Volksraad - subject only to the right of the public to lodge a wettig bezwaar (lawful objection) to any of the clauses. MW Pretorius was duly sworn in as "President of the Executive Council of the South African Republic" and Stephanus Schoeman as "Commandant-General and member of the Executive Council". Pretorius was then ceremoniously handed a copy of the Grondwet, the national flag and the national coat of arms, to the accompaniment of a twenty one cannon-gun salute.

The Zuid-Afrikaansche Republiek finally had a Grondwet, six long years after the idea had first been mooted. ${ }^{136}$

Schoeman had had his way. The role and function of the Commandant-General was effectively divorced from the (sole) authority of the President. The nomenclature used for the two senior positions was instructive: Pretorius was President, not of the Republic, but of the Executive Council of the Republic (a servant of the people, therefore, not a Napoleon); Schoeman was Commandant-General and also member of the Executive Council, his seat at the high table assured.

Bührmann also had his way. In the General Provisions section the Volksraad's supreme authority was entrenched. The all-important section 12 - source of so much later friction - provided as follows (translated from the original Dutch):

The people assigns [geeft ... in handen] legislative authority to a Volksraad, the highest authority in the land, comprising representatives or mandatories of the people, elected by enfranchised citizens; however, only to the extent that the people will be given a period of three months to provide its comments to the Volksraad on a proposed law should it wish to do so; except those laws which brook no delay.

It is no exemplar of drafting elegance. The article was complemented by a number of articles in the chapter on the Volksraad, entitled, instructively, Over den Volksraad, het hoogste Gezag, of de Wetgewende Magt (On the Volksraad, the Highest Authority, or the Legislative Power). This chapter was now placed before the chapter on the President and the executive authority, no doubt to confirm its precedence over the

135 The minutes of the meeting are published in Volksraadsnotule III at 163-169.

136 The Grondwet is published in Volksraadsnotule III at 496-524. See, too, Jeppe \& Kotzé 1887: 3568; Eybers 1918: 363-409 (with an accompanying English translation). 
executive authority. Article 29 stated that the Volksraad was the hoogste gezag des lands, en de Wetgewende magt (the highest authority in the land and the legislative power). Clearly, the intention was to draw a distinction between its legislative authority and its overall authority in governing the country. The Volksraad would comprise "at least twelve members" (to accommodate population growth and the demand for ongoing fully representative government); and members would be appointed for two years, to afford the volk an opportunity to regularly choose their representation in government. Rules were retained that made sure that draft laws were properly published for public comment for the obligatory three months; fines were retained for those officials found to be negligent in this regard; the President and the Executive Council were directed to make the judgement call whether the three-month notice period could be dispensed with in matters that brooked no delay; and it still remained the prerogative of the Volksraad chairman to allow or disallow the discussion of the law.

The events leading up to the final approval of the Grondwet were conflict-ridden and hostile to the point where actual armed violence was a real possibility. The anxious deliberations on the final wording of the Grondwet were conducted by the most influential men in the Republic (Pretorius, Schoeman and Bührmann) and their trusted advisers sitting around a table and striving for - and achieving - consensus. When reflecting on these circumstances and the actual formulations contained in the final product the following conclusions seem apparent: The King's voice (the koningstem) belonged to the people (the volk), not to the Volksraad and not to an autocratic President. William Robinson, chairperson of the drafting committee, said as much in early March 1858: "van Art. 1 tot Art. 28" [encompassing the General Provisions chapter and the second chapter on the Protection and Defence of Church and State] word duidelijk vastgesteld de koningstem van het Volk" (from arts 1-28 the King's voice of the people is clearly determined). ${ }^{137}$ The volk elected the President (for a five-year period) and the Commandant-General (for an indefinite period) and the volk approved, by means of an electoral process, the appointment of landdrosts from one or two persons proposed to it by the Executive Council. The President was constrained to comply with the wishes of the volk as far as possible in respect of the advancement and welfare of Church and State.

The Volksraad was not only the legislative authority, it was the supreme authority in the state, exercising an authority that superseded that of the President and of the judicial authority. The President was the first and highest official of the state, who proposed laws, but did not make them. The judicial authority (landdrosts, heemraden and jurymen) was, to be sure, completely free and independent, and judicial officers were to exercise that authority in accordance with their judgement and conscience. But, importantly, they were to do so in the application of the landswetten (national 
laws) approved by the Volksraad. The phrase, "in the application of the national laws", served as further confirmation that the judicial authority, though free and independent, was still obliged to apply the laws made by the Volksraad and therefore remained subject to the Volksraad's supreme authority. They applied the law, they did not make the law.

The Volksraad exercised that authority because the volk willed it to be so. Through a variety of mechanisms the volk still controlled the manner in which the members of the Volksraad exercised the mandate the volk had given them. It was important that the Volksraad exercised the highest authority in the state, because it could and did happen that no clarity existed as to what the views of the volk were when they exercised their King's voice. Proper means to accurately gauge the considered temper of the volk was absent and would remain absent. In practice the populist majority sentiment expressed at people's assemblies in the region where the Volksraad met became the default mechanism for the volk to have its voice heard. But in the unsettled regionalism of the times the volk's voice became not so much a sovereign voice as the voice of a dominant region exercising sway over the other regions. It was then up to the Volksraad, comprising regularly-elected mandatories of the volk, to employ their knowledge, wisdom and experience, to benefit from considered debate and judicious expressions of opinion, in order to take resolutions, make laws and otherwise govern the country in accordance with their understanding of volk-inspired wet en regt (law and justice). The volk had an opportunity every two years to replace its representatives if they did not govern lawfully and justly. They also had an opportunity with every law that was proposed to express their opinion on it.

On 18 February 1858 , therefore, six long years after Andries Pretorius had sought the advice of Andries Stockenström on how to go about writing a constitution for the Transvaal, a Grondwet approved by all finally came into being. It germinated in the crucible of Boer conflict, ignorance, prejudice, passion, stubbornness, strength, persistence and idealism. Its very authenticity, a demonstrable product of the wishes, hopes, passions and demands of the people for whom it was written, was both its strength and its weakness. Its strength, because as an expression of the volkstem, the will of the people, it retained a legitimacy that became ingrained in the psyche of the Boers. Its weakness, because it was very much a creature of its times. Attempts in later years to retain its essential features and to shun evolutionary change when, by the late $1880 \mathrm{~s}$, the society for which it had been crafted had irrevocably changed, became the stuff of artifice. The Grondwet was regularly amended largely to reinforce a style of government that belonged not to the gold-powered and cosmopolitan 1890 s but to the ox-paced agrarian world of the 1850s. This strength of and this weakness in the Grondwet fundamentally influenced the constitutional debate between President Paul Kruger and Chief Justice John Kotzé in the 1890s and led directly to the latter's dismissal. It permeated the futility of Robert Brown's quest to 
share in the wealth of the goldfields. It even contributed to the eventual demise of the volk as they succumbed to their own obstinacy and to British military supremacy in the war of 1899-1902.

\section{BIBLIOGRAPHY}

\section{Books}

Binckes R (2013) The Great Trek Uncut (Pinetown)

Beyers, C (1929) Die Kaapse Patriotte 1779-1791 (Cape Town)

Breytenbach, JH (ed) (1950) Notule van die Volksraad van die Suid-Afrikaanse Republiek II (Cape Town) (cited as Volksraadsnotule II)

Breytenbach, JH (ed) (1951) Notule van die Volksraad van die Suid-Afrikaaanse Republiek III (Cape Town) (cited as Volksraadsnotule III)

Breytenbach, JH (ed) (1952) Notule van die Volksraad van die Suid-Afrikaanse Republiek IV (Cape Town) (cited as Volksraadsnotule IV)

Breytenbach, JH \& Pretorius, HS (eds) (1949) Volksraadsnotule I (1844-1850) (Cape Town) (cited as Volksraadsnotule I)

Bryce, J (1901) Studies in History and Jurisprudence vol 2 (Oxford)

Dictionary of South African Biography vol IV (1981) (Durban) (cited as Dictionary of SA Biography vol IV)

Dulaure, A (1834) Histoire de Paris vol 4 (Paris)

Du Toit, A \& Giliomee, H (1983) Afrikaner Political Thought Analysis and Documents Volume Makro 1: 1780-1850 (Cape Town)

Eybers, GW (1918) Select Constitutional Documents Illustrating South African History 17951910 (London)

Ferreira, OJO (1978) Stormvoël van die Noorde (Pretoria)

Gey van Pittius, EFW (1941) Staatsopvattings van die Voortrekkers en die Boere (Pretoria)

Giliomee, H (2003) The Afrikaners Biography of a People (Cape Town \& Charlottesville)

Jeppe, F \& Kotzé, JG (1887) De Locale Wetten der Zuid Afrikaansche Republiek 1849-1885 (Pretoria)

Kotzé, JG (1894) Het Stichting der Zuid Afrikaansche Republiek en Haare Grondwet (Pretoria)

Krynauw, DW \& Pretorius, HS (eds) (1949) Transvaalse Afrgiefstukke Staatsekretaris Inkomende Stukke 1850-1853 (Cape Town)

Preller, GS (1918) Voortrekkermense vol 1 (Cape Town)

Pretorius, HS \& Krüger, DW (eds) (1937) Voortrekker-Argiefstukke 1829-1849 (Cape Town)

Schoeman, K (1995) Die Wêreld van Susanna Smit, 1799-1863 (Cape Town)

Strauss, DFM (2008) "Transformasie en die Regstaat (Burgerstaat): Tussen die Scylla van die Herstel van Begane Onreg en die Charybdis van 'n Ondemokratiese Magstaat wat aan die Slagspreuk 'Verteenwoordigend van die Demografie' gegee word" Tydskrif vir Geesteswetenskappe 48(1): 58-77 
Swart, MJ (1963) Teodor Hendrik Bührmann. Sy Rol in die Transvaalse Republiek (Cape Town) Thom, HB (1947) Die Lewe van Gert Maritz (Cape Town)

Thompson, LM (1954) "Constitutionalism in the South African Republics" Butterworths South Africa Law Review 1: 49-72

Van der Merwe, D (1994) "Die Drie-en-Dertig Artikels: 150-jarige simbool van 'n vergane regsoortuiging" De Jure 27(2): 366-376

Van Jaarsveld, FA(1951) Die Eenheidstrewe van die Republikeinse Afrikaners vol 1 (Johannesburg)

Van Oordt, JF (1898) Paul Kruger en de Opkomst der Zuid-Afrikaansche Republiek (Cape Town)

Walker, EA (1934) The Great Trek (London)

Wichmann, FAF (1941) Die Wordingsgeskiedenis van die Zuid-Afrikaansche Republiek (Cape Town)

Wildenboer, L (2015) "The Thirty-Three Articles and the application of law in the ZuidAfrikaansche Republiek" Fundamina 21(2): 457-476

Wypkema, A (1939) “Die Volkstemidee in Suid-Afrika” Historiese Studies 1(1): 48-59

Wypkema, A(1949) Die Invloed van Nederland op Ontstaan en Ontwikkeling van Staatsinstellingen $\operatorname{der}$ Z.A. Republiek (Pretoria)

\section{Cases}

Brown v Leyds NO (1897) 4 OR 17

Robert E Brown (United States) v Great Britain Reports of the International Arbitral Awards (RIAA) VI 120 